\title{
Environmental and Economic Benefits of Some Air Pollutants Control Case Study: Emissions from different Boilers of different Factories
}

\author{
Ashraf A. Zahran (Corresponding author) \\ Department of Natural Resources and Planning to Development \\ Environmental Studies and Research Institute (ESRI), University of Sadat City, Egypt \\ Tel: 20-122-757-8724Ｅ-mail: Ashraf_zahran@amatec-az.com
}

A. M. Arafa

Egyptian Environmental Affair Agency, Egypt

A. M. Alaam

Department of Natural Resources and Planning to Development

Environmental Studies and Research Institute (ESRI), University of Sadat City, Egypt

\author{
G. El Saiedy
}

Egyptian Environmental Affair Agency, Egypt

Received: November 29, 2019 Accepted: December 23, 2019 Published: January 26, 2019

doi:10.5296/emsd.v9i1.16352

URL: https://doi.org/10.5296/emsd.v9i1.16352

\begin{abstract}
This search is evidence that development plans and environmental conservation go in one direction, where we can decrease environmental pollution with economic benefits simultaneously. By monitoring emissions from four boilers stacks (from petrochemical and food sectors) which working by natural gas. Changes in excess air were conducted to increase combustion efficiency means fuel savings, and decrease pollutant concentration, where there is a relationship between cost, combustion, stack heat loss, fuel-saving, and environment. Combustion efficiency and emitted pollutants from the stacks were measured before and after
\end{abstract}




\section{Macrothink}

maintenance, where mixed-air with fuel is changed. In boiler 1 of petrochemical sector, carbon monoxide changed from 2222 to $21 \mathrm{mg} / \mathrm{m}^{3}$. In boiler 2, CO changed from 4695.3 to $5.5 \mathrm{mg} / \mathrm{m}^{3}$. The efficiency of boiler 1 and 2 improved from $75.5 \%$ to $92.1 \%$, and from 71.5 to $93.1 \%$ respectively. In boiler 1 of food sector CO changed from 2200 to $45 \mathrm{mg} / \mathrm{m}^{3}$. In boiler 2 , CO changed from 1900 to $59 \mathrm{mg} / \mathrm{m}^{3}$. The efficiency of boiler1 and 2 improved from $69.8 \%$ to $91.4 \%$, and from $76.5 \%$ to $91.1 \%$ respectively. The cost reduction per year was $8469.1 \$$ and $11692.8 \$$ in the petrochemical sector, while it was $11624.4 \$$ and $12168.2 \$$ in the food sector. Where the cost of maintenance for each boiler was $100,000 \$$, the payback time is 5.11 years for boiler 1 in the petrochemical sector and 3.99 years for boiler 2, while the payback time is 3.86 years for boiler 1 in the food sector and 5.68 years for boiler 2 .

Keywords: Air pollution, Pollution control, Excess air, Combustion efficiency, Fuel saving, Cost reduction, Payback time, and stack heat loss

\section{Abbreviations:}

AQL Air Quality Limit (Egyptian environmental law)

AT Ambient temperature

BTU British Thermal Unit

Com. Eff Combustion efficiency

EEAA Egyptian Environmental Affairs Agency

Eff Efficiency

FHV Fuel Heat Value

FT Flue Temperature

IHME Institute for Health Metrics and Evaluation

SHL Stack Heat Loss

UNEP United Nations Environment Programme

\section{Introduction}

The objective of this work is to establish a system for environmental and economic benefits of controlling some air pollutants emitted from a boiler of a factory.

\subsection{Air Pollution}

Any solid, liquid, or gas that is present in the air in a concentration that causes some deleterious effect is considered an air pollutant (Cooper et al., 1986).

Air pollution is considered to be one of the major problems in several cities around the world. Sources of air pollution may be natural such as volcanoes and Earthquakes or anthropogenic from industrial activities, waste treatment plants, transportation, ...etc. The worldwide effects of air pollution on public health are at present imprecisely known. It is likely that different 


\section{Macrothink}

hazards exist in different countries. Besides, no planning for site location of industry, from air pollution point of view, had ever been taken into consideration. This serious problem arose from the rapid growth of industrialization and urbanization (Sengupta et al., 1994).

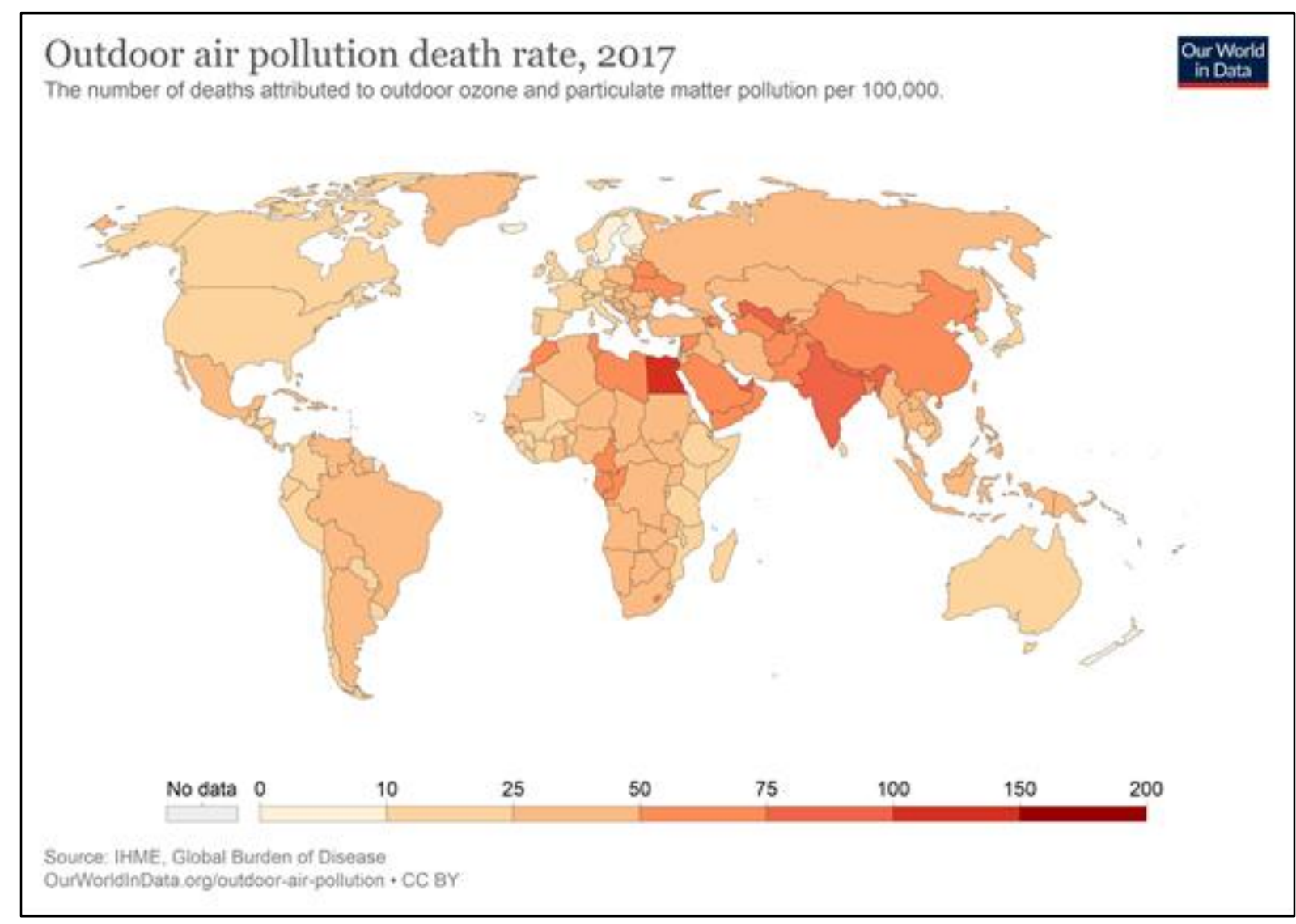

Figure 1. Outdoor air pollution death rate, 2017 (Global Burden of Disease Collaborative Network, 2018)

A survey of measurements of various types of air pollutants "Nitrogen Dioxide $\left(\mathrm{NO}_{2}\right)$, Sulphur Oxides $\left(\mathrm{SO}_{\mathrm{x}}\right)$, and Carbon Monoxide (CO)" emitted from boilers was done in two types of industrial sectors (petrochemical and food sectors). Furthermore, the calculation of fuel-saving, cost reduction, and impact on public health was discussed.

\subsection{Energy}

Energy is the ability of a material or system to perform labor (Knospe et al., 2004). There is a strong linkage between energy efficiency and environmental impact as, for the same service or product, less resource utilization and pollution are usually associated with increased energy efficiency (Dincer et al., 2011).

\subsection{Fuel}

A fuel is any material that can be made to react with other substances in order to produce energy in the form of heat through a process called combustion. (Muhammad et al., 2018). Every fuel has a unique composition and energy content described by its fuel specifications. Fuel specs are essential to determine combustion parameters such as combustion efficiency, 


\section{Macrothink}

minimum air requirements, Carbon Dioxide $\left(\mathrm{CO}_{2}\right)$ concentration, and emissions factors (TSI incorporated, 2004).

\subsection{Combustion}

Combustion is the conversion of primary chemical energy contained in fuels to secondary energy (heat) through the oxidation process (TSI incorporated, 2004).

Releasing a hundred percent of the fuel heat is the objective of good combustion. It can be achieved by controlling the "three T's" of combustion which are:

(1) Temperature "high enough to start and maintain the ignition of the fuel".

(2) Turbulence "mixing of the fuel and oxygen at the discharge of the burner in the case of gas and oil-fired boiler", and

(3) Time "sufficient for complete combustion" (UNEP, 2006).

Required oxygen for a combustion process is supplied as a part of the combustion air which consists of nitrogen $\left(\mathrm{N}_{2}\right)$, oxygen $\left(\mathrm{O}_{2}\right)$, a small amount of Carbon Dioxide $\left(\mathrm{CO}_{2}\right)$ and rare gases, and variable content of water vapor. Sometimes, pure oxygen or an air/oxygen mixture is used for the combustion. Except for oxygen, all combustion air components are contained in the resulting raw flue gas. (Knospe et al., 2004).

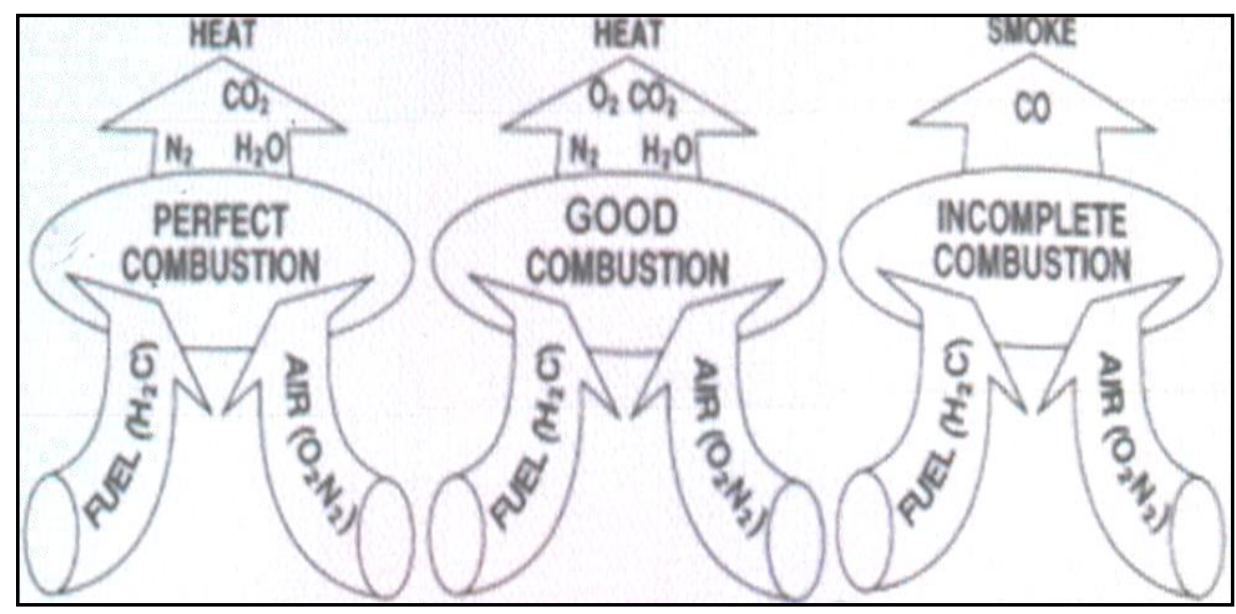

Figure 2. Perfect, good and incomplete combustion (Knospe et al., 2004)

The simplest example of hydrocarbon fuel combustion is the reaction of methane $\left(\mathrm{CH}_{4}\right)$, the major component of natural gas, with oxygen in the air. When this reaction is balanced, each molecule of $\mathrm{CH}_{4}$ reacts with two molecules of $\mathrm{O}_{2}$ producing one molecule of $\mathrm{CO}_{2}$ and two molecules of $\mathrm{H}_{2} \mathrm{O}$. When this occurs, the energy released as heat.

$$
\begin{gathered}
\mathrm{CH} 4+2 \mathrm{O}_{2} \rightarrow \mathrm{CO}_{2}+2 \mathrm{H}_{2} \mathrm{O} \\
\text { Reactants } \rightarrow \text { Products }+ \text { Heat }
\end{gathered}
$$

In actual combustion processes, other products such as $\mathrm{CO}, \mathrm{NO}, \mathrm{NO}_{2}$, and $\mathrm{SO}_{2}$ are usually formed. A typical example of an actual combustion process is shown in Figure 3. Fuel has 


\section{Macrothink

reacted with air to produce the products shown on the right.

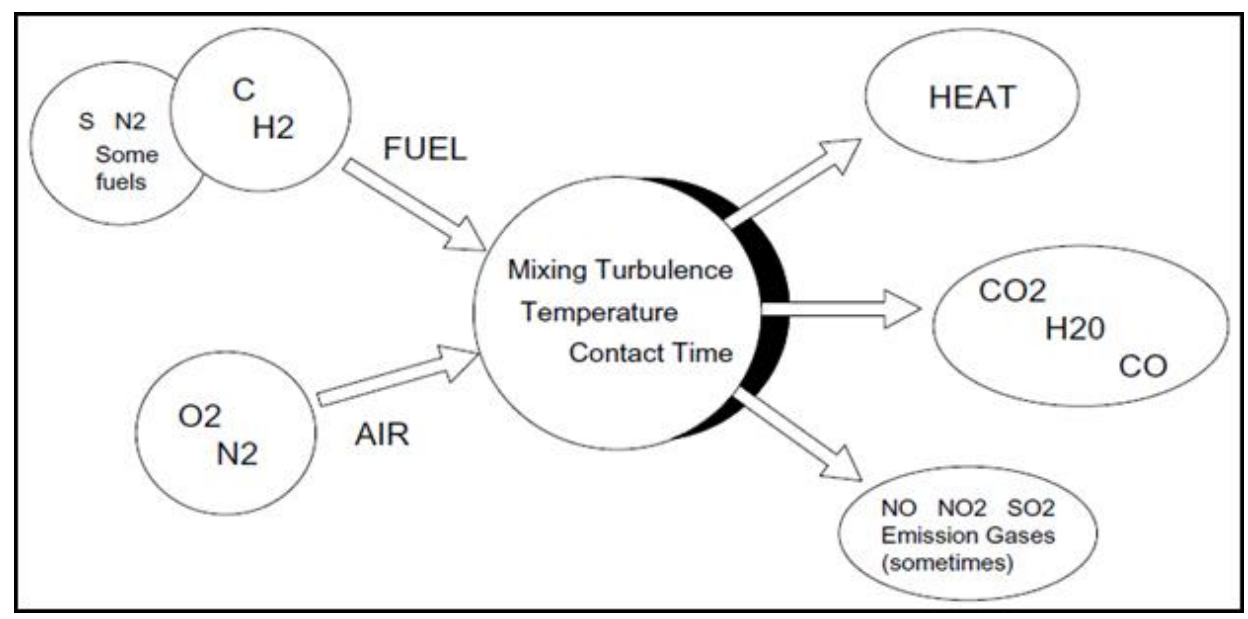

Figure 3. combustion diagram (TSI incorporated 2004)

The combining of $\mathrm{O}_{2}$ (in the air) and $\mathrm{C}$ (in the fuel) to generate $\mathrm{CO}_{2}$ and heat is a complex process that requires right mixing turbulence, sufficient activation temperature and adequate time for the reaction. Unless combustion is duly controlled, high concentrations of undesirable products can be formed such as $\mathrm{CO}$ and soot from poor fuel/air mixing or too little air. Other undesirable emissions, such as nitrogen oxides $\left(\mathrm{NO}, \mathrm{NO}_{2}\right)$, can be formed in high concentrations when the burner flame temperature is too high. If fuel contains sulfur, $\mathrm{SO}_{2}$ gas will be formed. For solid fuels such as coal and wood, ash will be generated from incombustible materials in the fuel. (TSI incorporated 2004).

As a rule, the most efficient and cost-effective usage of fuel occurs when the $\mathrm{CO}_{2}$ concentration is maximized in the exhaust. This occurs theoretically when there is just enough $\mathrm{O}_{2}$ in the supplied air to react with all the carbon in the fuel. This quantity of supplied air is often referred to as "the theoretical air". The theoretical air required for the combustion reaction depends on fuel composition and the rate of fuel usage (e.g. pounds/hour, cubic/minute, ... etc.). Actually, factors such as the burner condition and design also influence the air amount that is needed (TSI incorporated 2004).

The ideal combustion "stoichiometric combustion" procedure is shown schematically in figure (4). The $\mathrm{O}_{2}$ amount supplied to the combustion is just sufficient to burn all fuel combustibles completely. No $\mathrm{O}_{2}$ or fuels are left. The excess air value is (1) in this case. 


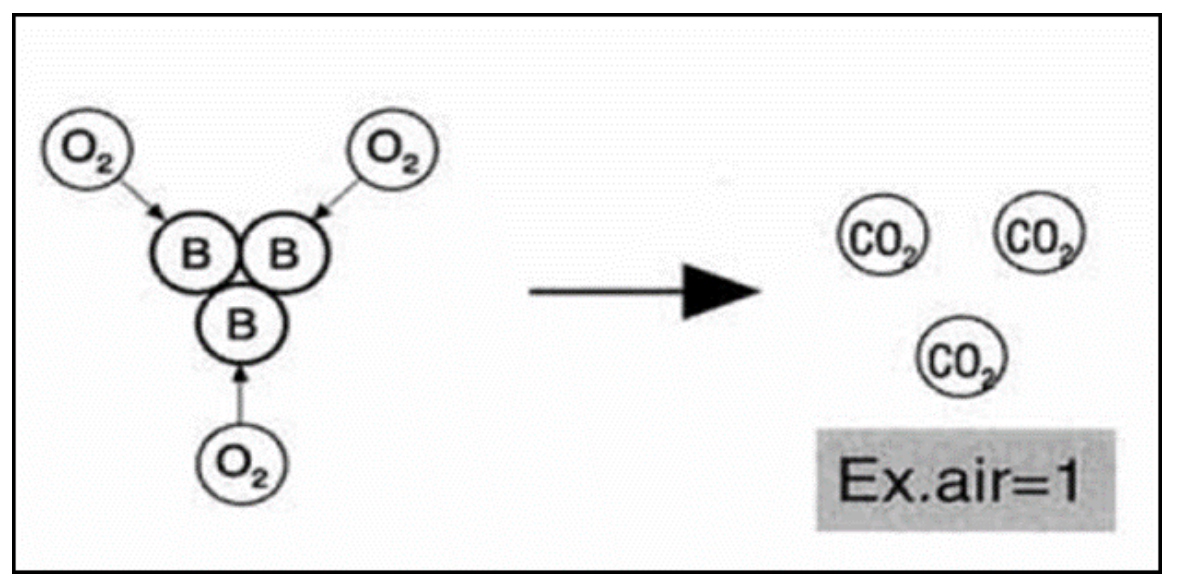

Figure 4. Stoichiometric combustion model (Knospe et al., 2004)

Practically, this ideal $\mathrm{O}_{2}$ volume is not sufficient for complete burning due to insufficient fuel and $\mathrm{O}_{2}$ mixing. And hence, the combustion process must be supplied with more than the stoichiometric volume of $\mathrm{O}_{2}$. This additional amount of combustion air is called "excess air", the percent air above the theoretically needed amount for complete combustion, and the ratio of the total air volume to the stoichiometric air volume is the excess air value ex. air. Figure (5) shows this excess air combustion model (ex. air>1) schematically.

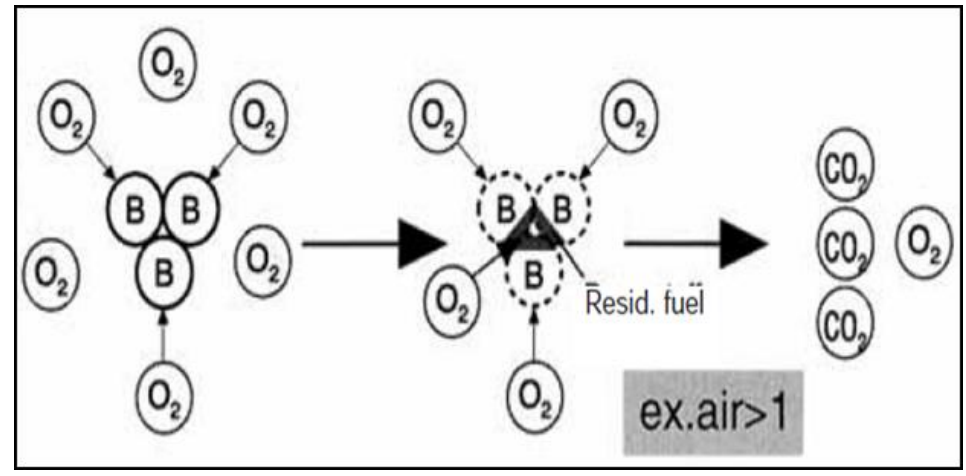

Figure 5. Excess air combustion model (Knospe et al., 2004)

Consequently, the highest efficiency of combustion can be achieved with a (limited) excess $\mathrm{O}_{2}$ volume, i.e. ex. air $>1$ (oxidizing atmosphere). The excess air value is critical for optimizing the combustion process and economic operation as unnecessary high ex. air volumes reduce combustion temperatures and increase the energy loss released unused into the atmosphere via the hot flue gas stream, while some combustible components of the fuel remain unburned using too little excess air. This reduces combustion efficiency and increases air pollution because of emitting the unburned components to the atmosphere (Knospe et al., 2004).

The ex. air value can be specified from $\mathrm{CO}, \mathrm{CO}_{2}$, and $\mathrm{O}_{2}$ concentrations of in the flue gas. Figure (6) shows these relations in the combustion scheme, at ideal fuel/air mixing conditions, each $\mathrm{CO}_{2}$ content value is related to:

- a certain CO value (area with ex. air <1), or 
- a certain $\mathrm{O}_{2}$ value (area with ex. air>1).

The $\mathrm{CO}_{2}$ value for itself is not definite because of the curve showing a maximum. Therefore, it must additionally be checked whether, besides the $\mathrm{CO}_{2}, \mathrm{CO}$ or $\mathrm{O}_{2}$ is present in the gas. When operating the combustion with excess air (i.e. the normal case) nowadays the definite determination of $\mathrm{O}_{2}$ only is preferred (Knospe et al., 2004).

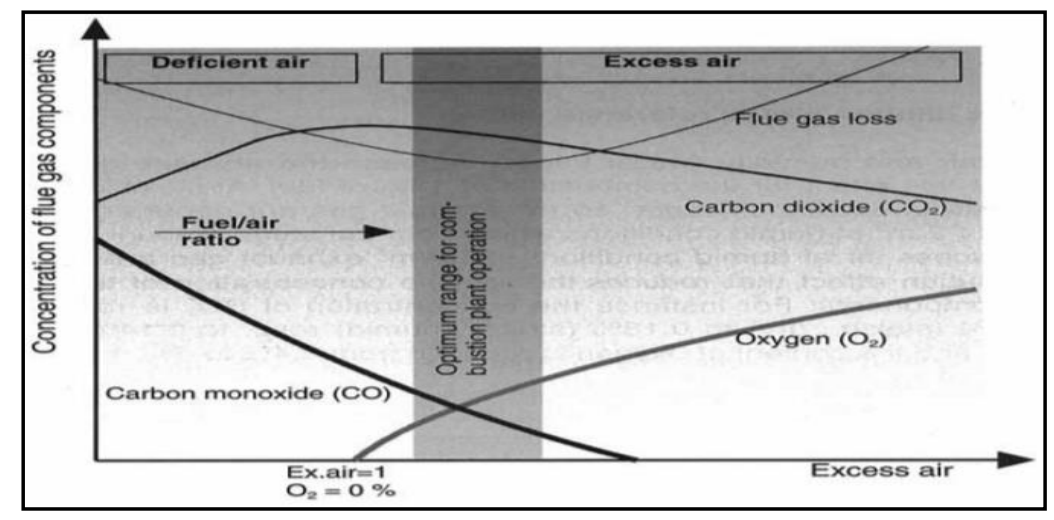

Figure 6. Combustion diagram (Knospe et al., 2004)

In most stationary sources, the airflow to the combustor is controlled, in part, by measuring the excess air and maintaining a fixed excess air level. Controlling excess air exactly is now an integral part of the air pollution control systems used in combustion source evaluation automobiles as well as many stationary sources (Brian, 2003).

There is a simple relationship between excess air and flue gas oxygen concentration, given by Equation 1 (Brian, 2003).

$$
\% \text { Excess Air }=\frac{\% 02}{20.9-\% 02} \times 100
$$

This calculation uses the oxygen concentration measured in the exhaust gas. If the $\mathrm{CO}$ concentration is very high, it may also be included in the excess air calculation. This is shown in the following equation (Brian, 2003).

$$
\% \text { Excess Air }=\frac{\% 02-\frac{\% c o}{2}}{20.9-\left(\% 02-\frac{\% C O}{2}\right)} \times 100
$$

Adding additional excess air is often done to reduce the $\mathrm{CO}$ concentration. Too much excess air can actually have the reverse effect of increasing CO. This occurs when fuel and air no longer mix properly in the burner, reducing the contact time between oxygen and fuel, and hence inhibiting a complete reaction. Figure (7) shows how increasing excess air reduces combustion efficiency. 


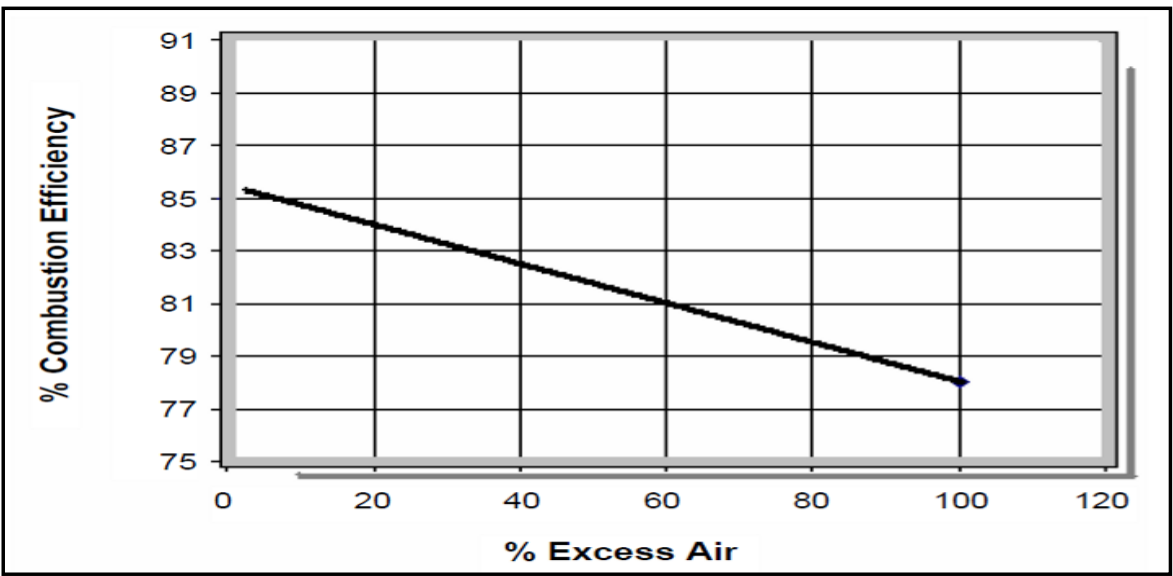

Figure 7. \% combustion efficiency vs. \% excess air (fuel oil) (TSI incorporated, 2004)

The efficiency of combustion is a measure of how energy from the fuel is converted effectively into useful energy (e.g. to create steam). (TSI incorporated (2004).

$$
\% \text { Combustion Effeciency }=100 \%-\left[\frac{\text { Stach Heat Loss }}{\text { Feul Heating Value }} \times 100\right]
$$

Stack heat losses occur primarily due to the heated dry exhaust gases $\left(\mathrm{CO}_{2}, \mathrm{~N}_{2}, \mathrm{O}_{2}\right)$ and water vapor formed from the reaction of $\mathrm{H}_{2}$ in the fuel with $\mathrm{O}_{2}$ in the air, figure (8). Where heat escaping the exhaust flue with the hot gases is not transferred to do useful work, such as producing steam (TSI incorporated, 2004).

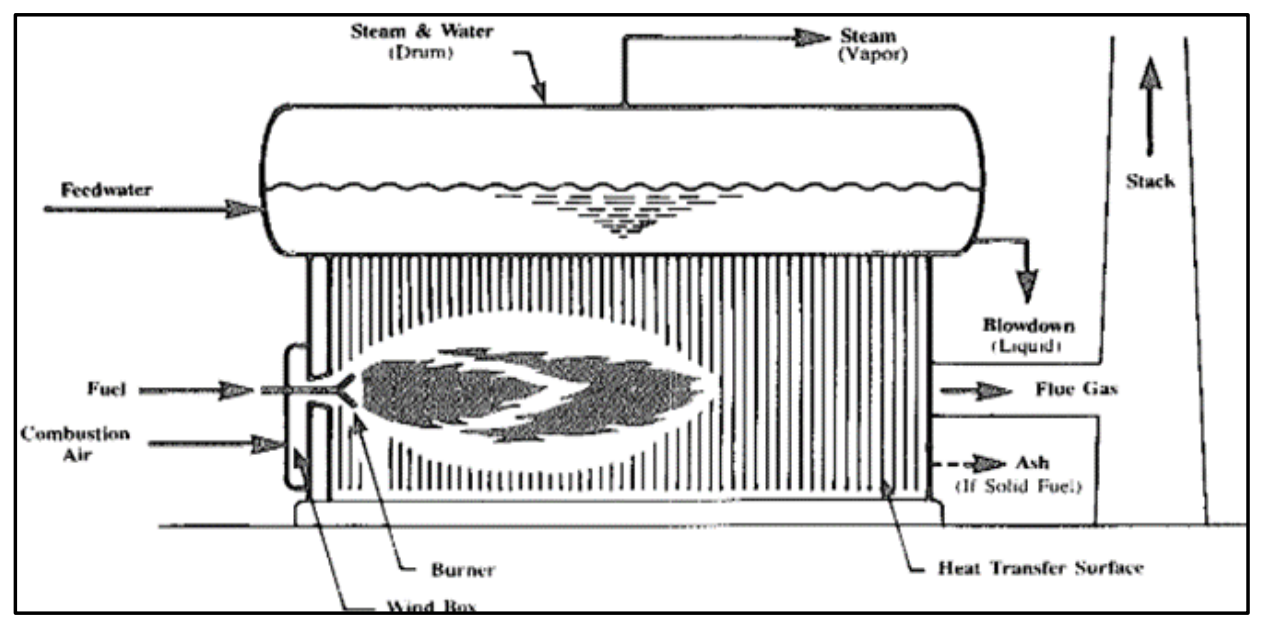

Figure 8. Basic components of the boiler (Boiler plant system, 1980)

The heat loss becomes a major cause of lower combustion efficiency. The heat content of the flue gas is directly proportional to its temperature and therefore the combustion efficiency declines as the temperature increases. An example of efficiency loss due to the increase in temperature of flue gas is shown in figure (9) (TSI incorporated 2004). 


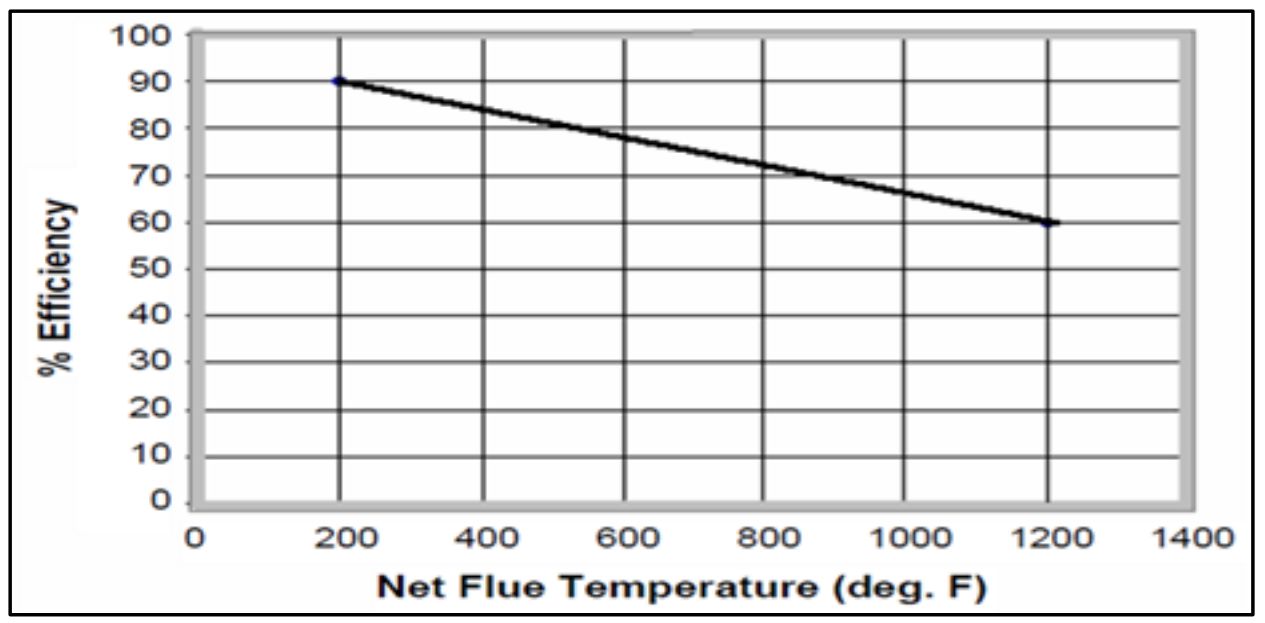

Figure 9. Flue temperature vs. \% Efficiency (fuel oil) (TSI incorporated 2004)

Combustion efficiency, determined from combustion analysis, is a cost-effective way to improve equipment operation and reduce fuel expenses (TSI incorporated (2004).

\subsection{Boiler}

Boilers are used to generate steam or hot water. The basic components of the boiler can be shown schematically (Fig 8) (kuprianov I.V, 2004).

One of the major requirements for the operation of utility and industrial boilers is to provide the maximum possible thermal efficiency with a minimum impact on the environment. For a particular boiler, excess of combustion air (or excess air ratio, $\alpha$ ) is the main operating variable affecting the boiler's thermal efficiency simultaneously, operational reliability, and environmental performance (emissions from the boiler) (kuprianov I.V, 2004).

\section{Material and Methods}

\subsection{SENSONIC 2000 Portable Analyzer}

Stack gases emissions were measured using SENSONIC 2000 portable analyzer, which is a microprocessor-controlled environment with pre-calibrated electrochemical cells and temperature sensor for the optimum adjustment of boilers, furnace, kilns, and the monitoring of industrial emissions (Sensonic 2000 manual).

\subsection{Electrochemical Sensors}

Sensors are suitable for the determination of $\mathrm{O}_{2}, \mathrm{CO}, \mathrm{SO}_{2}$ and $\mathrm{NO}_{\mathrm{x}}$ according to the electrochemical principle of ion-selective potentiometry. The sensors are filled, specifically for their measuring task, with an aqueous electrolytic solution. Two or three electrodes (again task-specific) are placed in the solution with an electrical field applied to them. The sensors are sealed to the outside with a gas-permeable membrane, see fig. 10 and 11. Detailed design and operating principle differ depending on the gas component to be measured as shown in the following two examples:

Example 1: Sensor for oxygen (2 electrodes) 


\section{Macrothink}

The flue gas resp. the oxygen molecules pass through the membrane and reach the sensor cathode. Because of the material composition of the cathode, a chemical reaction takes place resulting in the release of $\mathrm{OH}$ - -ions (ions = charged particles) from the cathode. The free ions migrate through the liquid electrolyte to the anode of the sensor thus generating an electric current in the external electrical circuit that is proportional to the oxygen concentration.

This current creates a voltage drop across the resistor $\mathrm{R}$, which is the measuring signal and used for further electronic processing. The integral resistor is a thermistor with a negative temperature coefficient, NTC. It serves to compensate for temperature influences and thus ensures thermally stable sensor performance (Knospe et al., 2004).

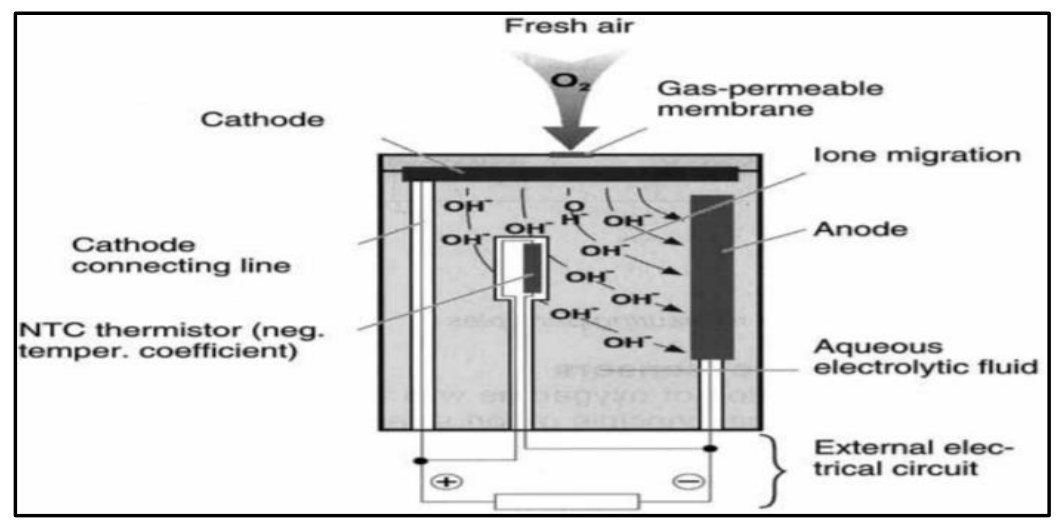

Figure 10. Schematic of an Oxygen sensor (Knospe et al., 2004)

Example 2: Sensors for $\mathrm{CO}, \mathrm{SO} 2$, and $\mathrm{NOx}$ (three electrode sensor)

To determine gases such as $\mathrm{CO}, \mathrm{SO}_{2}$ or $\mathrm{NO}_{\mathrm{x}}$, three-electrode sensors are used. The operating principle is explained in the following using the $\mathrm{CO}$ sensor as an example.

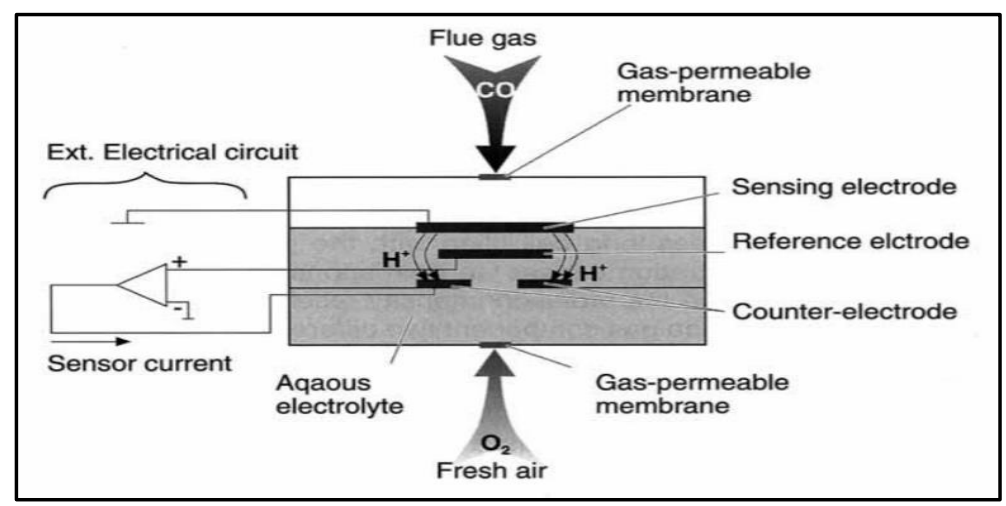

Figure 11. Schematic of a Carbon monoxide sensor (Knospe et al., 2004)

The carbon monoxide (CO) molecules pass through the gas-permeable membrane to the sensing electrode of the sensor. There a chemical reaction takes place that results in the formation of $\mathrm{H}+$-ions migrating from the sensing electrode to the counter electrode. At the counter electrode, a second chemical reaction occurs with the aid of oxygen delivered from fresh air. This second reaction causes a current to flow in the external circuit. The current can 


\section{Macrothink}

be evaluated as a measure of the carbon monoxide concentration. The reference electrode is used to stabilize the sensor signal (Knospe et al., 2004).

\subsection{Equations of Calculations}

2.3.1 Stack Heat Loss (TSI Incorporated (2004)

$$
\% \text { Combustion Effeciency }=100 \%-\left[\frac{\text { Stach Heat Loss }}{\text { Feul Heating Value }} \times 100\right]
$$

2.3.2 Fuel Saving (Gearo et al., 1983)

$$
\text { Estimated fuel savings }=\frac{(\text { Improved efficiency-original efficiency })}{\text { Improved efficiency }} \times 100
$$

\subsubsection{Cost Reduction}

Cost reduction was calculated from stack heat loss reduction after improvement and the cost of reduced stack heat loss through the following equations

$$
\begin{gathered}
\text { SHL reduction }=\text { SHL(before improvement })- \text { SHL(after improvement) } \\
\text { Cost reduction }=\text { SHL reduction }(\text { MMBtu }) \times \text { price of } 1 \text { MMBtu }
\end{gathered}
$$

\subsubsection{Efficiency and Payback Time}

\subsubsection{Efficiency}

Combustion efficiency is used for calculation of fuel saving as in equation 5.

\subsubsection{Payback Time}

The payback time of an energy-saving solution is a measure of how cost-effective it (https://www.bbc.co.uk/bitesize/guides/z3xb4qt/revision/7).

$$
\text { Payback time }(\text { years })=\left(\frac{\text { Cost of installation }(£)}{\text { Savings per year in fuel costs }(£)}\right)
$$

\section{Results and Discussion}

This part includes results and discussion of measurements of different parameters such as $\mathrm{CO}$, $\mathrm{NO}, \mathrm{NO}_{2}, \mathrm{NO}_{\mathrm{x}}, \mathrm{SO}_{2}, \mathrm{O}_{2}, \mathrm{CO}_{2}$, which emitted from boilers, flue temperature, ambient temperature, and efficiency in two industrial sectors (Food and petrochemical) before and after corrective actions.

\subsection{Measuring Data from Boilers in Petrochemical Sector}

The concentrations of Carbone monoxide $\left(\mathrm{mg} / \mathrm{m}^{3}\right)$ were measured in two boilers and recorded levels were higher than Air Quality Limit AQL and all remaining parameters (NO, $\mathrm{NO}_{2}, \mathrm{NO}_{\mathrm{x}}, \mathrm{SO}_{2}$ ) were lower than AQL but it seems to be improved. By the way, $\mathrm{O}_{2}$ and $\mathrm{CO}_{2}$ were not adjusted so this situation makes trouble in the combustion and make it uncompleted. After corrective action, the measurements were done again and gave a good result as follows. 


\section{Macrothink}

\subsubsection{Percentage of CO Improvement in Boiler 1}

Carbone monoxide reached $2222 \mathrm{mg} / \mathrm{m}^{3}$ before any action, that means it increased 8.9 times of AQL. So, this value reached $888.8 \%$ of AQL. On the other hands, the concentration of CO after the corrective action (maintenance) reached $21 \mathrm{mg} / \mathrm{m}^{3}$, so the percentage of this value after the maintenance reached $8.4 \%$. The improvement of this action is $880.4 \%$ as shown in figure (1and 2) and table (1).

\subsubsection{Percentage of CO Improvement in Boiler 2}

Carbone monoxide was $4695.3 \mathrm{mg} / \mathrm{m}^{3}$ before any action, that's mean it increased 18.7 times of AQL. So, this value was $1878.12 \%$ of AQL. On the other hand, the concentration of CO after corrective action reached $5.5 \mathrm{mg} / \mathrm{m}^{3}$, so the percentage of this value after maintenance reached $2.2 \%$. The improvement of this action is $1875.92 \%$ as shown in figure (12 and 13) and table 1.

Table 1. Pollutants mission from stacks of boilers in a petrochemical company

\begin{tabular}{|c|c|c|c|c|c|c|c|c|c|c|}
\hline Parameters & FT $^{\circ} \mathrm{C}$ & $\mathbf{A T}^{\circ} \mathbf{C}$ & $\mathbf{O}_{2} \%$ & $\begin{array}{l}\mathrm{CO}_{2} \\
\% \\
\end{array}$ & $\begin{array}{l}\mathrm{CO} \\
\mathbf{m g} / \mathbf{m}^{3}\end{array}$ & $\begin{array}{l}\text { NO } \\
\mathbf{m g} / \mathbf{m}^{3}\end{array}$ & $\begin{array}{l}\mathrm{NO}_{2} \\
\mathrm{mg} / \mathrm{m}^{3} \\
\end{array}$ & $\begin{array}{l}\mathrm{NO}_{\mathrm{x}} \\
\mathbf{m g} / \mathbf{m}^{3}\end{array}$ & $\begin{array}{l}\mathrm{SO}_{2} \\
\mathrm{mg} / \mathrm{m}^{3}\end{array}$ & $\begin{array}{l}\text { Eff. } \\
\%\end{array}$ \\
\hline $\mathrm{AQL}$ & & & & & 250 & & & 300 & 1600 & \\
\hline \multicolumn{11}{|c|}{ Fuel Type: Natural Gas (Petrochemical sector) } \\
\hline Boiler 1 Before & 242 & 33 & 14.22 & 3.76 & 2222 & 24.2 & 0 & 24.2 & 7.98 & 75.5 \\
\hline$\%$ according to $\mathrm{AQL}$ & & & & & 888.8 & & & 8.07 & 0.49 & \\
\hline Boiler1 After & 340 & 36 & 8.9 & 4.6 & 21 & 20.1 & 0 & 20.1 & 4.6 & 92.1 \\
\hline$\%$ according to $\mathrm{AQL}$ & & & & & 8.4 & & & 6.7 & 0.28 & \\
\hline$\%$ of improvement & & & & & 880.4 & & & 1.37 & 0.21 & 18.02 \\
\hline Boiler 2 Before & 236 & 33 & 0.65 & 11.34 & 4695.3 & 64.2 & 0 & 64.2 & 61.18 & 71.4 \\
\hline$\%$ according to $\mathrm{AQL}$ & & & & & 1878.12 & & & 21.4 & 3.86 & \\
\hline Boiler 2 After & 312 & 34 & 9.2 & 5.1 & 5.5 & 19.2 & 0 & 19.2 & 3.1 & 93.1 \\
\hline$\%$ according to $\mathrm{AQL}$ & & & & & 2.2 & & & 6.4 & 0.19 & \\
\hline$\%$ of improvement & & & & & 1875.92 & & & 15 & 3.6 & 23.31 \\
\hline
\end{tabular}

\subsubsection{Percentage of $\mathrm{NO}_{\mathrm{x}}$ Improvement in Boiler 1}

Nitrogen oxides were within AQL in both cases before and after maintenance, but its concentration decreased from $24.2 \mathrm{mg} / \mathrm{m}^{3}$ to $21.1 \mathrm{mg} / \mathrm{m}^{3}$ after corrective action. The percentage of improvement is $1.37 \%$ as shown in figures (14 \& 15) and table (1).

\subsubsection{Percentage of $\mathrm{NO}_{\mathrm{x}}$ Improvement in Boiler 2}

Nitrogen oxides were within AQL in both cases before and after maintenance, but its concentration decreased from $64.2 \mathrm{mg} / \mathrm{m}^{3}$ to $19.2 \mathrm{mg} / \mathrm{m}^{3}$ after corrective action. The percentage of improvement is $15 \%$ as shown in figure (14 \& 15) and table (1).

\subsubsection{Percentage of $\mathrm{SO}_{2}$ Improvement in Boiler 1}

Sulfur dioxide was within AQL in both cases before and after maintenance, but its concentration decreased from $7.98 \mathrm{mg} / \mathrm{m}^{3}$ to $4.6 \mathrm{mg} / \mathrm{m}^{3}$ after corrective action. The percentage of improvement is $0.21 \%$ as shown in figure $(16 \& 17)$ and table (1)

\subsubsection{Percentage of $\mathrm{SO}_{2}$ Improvement in Boiler 2}




\section{Ml Macrothink}

Environmental Management and Sustainable Development

ISSN 2164-7682

2020, Vol. 9, No. 1

Sulfur dioxide was within AQL in both cases before and after maintenance, but its concentration decreased from $61.2 \mathrm{mg} / \mathrm{m}^{3}$ to $3.1 \mathrm{mg} / \mathrm{m}^{3}$ after the corrective action. The percentage of improvement is $3.6 \%$ as shown in figure (16 \& 17) and table (1).

3.1.7 Percentage of Combustion Efficiency Improvement in Boiler 1 and Boiler 2 in Petrochemical Sector

According to the improvement of all parameters such as $\mathrm{CO}, \mathrm{NO}_{\mathrm{X}}$, and $\mathrm{SO}_{2}$, the efficiency of boiler 1 and boiler 2 improved from $75.5 \%$ to $92.1 \%$, and from 71.4 to 93.1 respectively. So, all these improvements help the company to save fuel, increase the lifetime of the boiler, and decrease emissions impact on public health, as shown in figure 18 and table (1).

\subsubsection{Boiler 1 and Boiler 2 Flue Temperature Change in Petrochemical Sector}

Flue gas temperature (FT) is an indication of how effectively the boiler water combustion heat is being transferred to. Generally, lower flue gas temperature indicates better heat transfer and higher overall efficiency. The temperature of boiler 1 and boiler 2 changed from $242^{\circ} \mathrm{C}$ to $340^{\circ} \mathrm{C}$ and from $236^{\circ} \mathrm{C}$ to $312^{\circ} \mathrm{C}$ respectively as shown in figure 19 and table 1.

\subsection{9 $\mathrm{O}_{2} \%$ Improvement Inside Boiler 1 and Boiler 2 in Petrochemical Sector}

Percentage of $\mathrm{O}_{2}$ is one of the very important parameters which play an essential role in complete combustion. The change in $\mathrm{O}_{2}$ inside boiler 1 and boiler 2 improved from $14.22 \%$ to $8.9 \%$ and from $0,65 \%$ to $9.2 \%$ respectively, according to these changes in $\% \mathrm{O}_{2}$, the efficiency of burning in boiler1 and boiler 2 improved and reached suitable ration for $\mathrm{O}_{2}$. On the other hand, $\mathrm{CO}_{2}$ changed from $3.76 \%$ to $9.2 \%$ and from $11.34 \%$ to $5.1 \%$ in boiler 1 and boiler 2 respectively. All these adjustments of $\mathrm{O}_{2}$ and $\mathrm{CO}_{2}$ are indirect ways to help company saving fuel, increasing lifetime of the boiler, and decreasing emissions from the stack as shown in figure (20 and 21) and table (1).

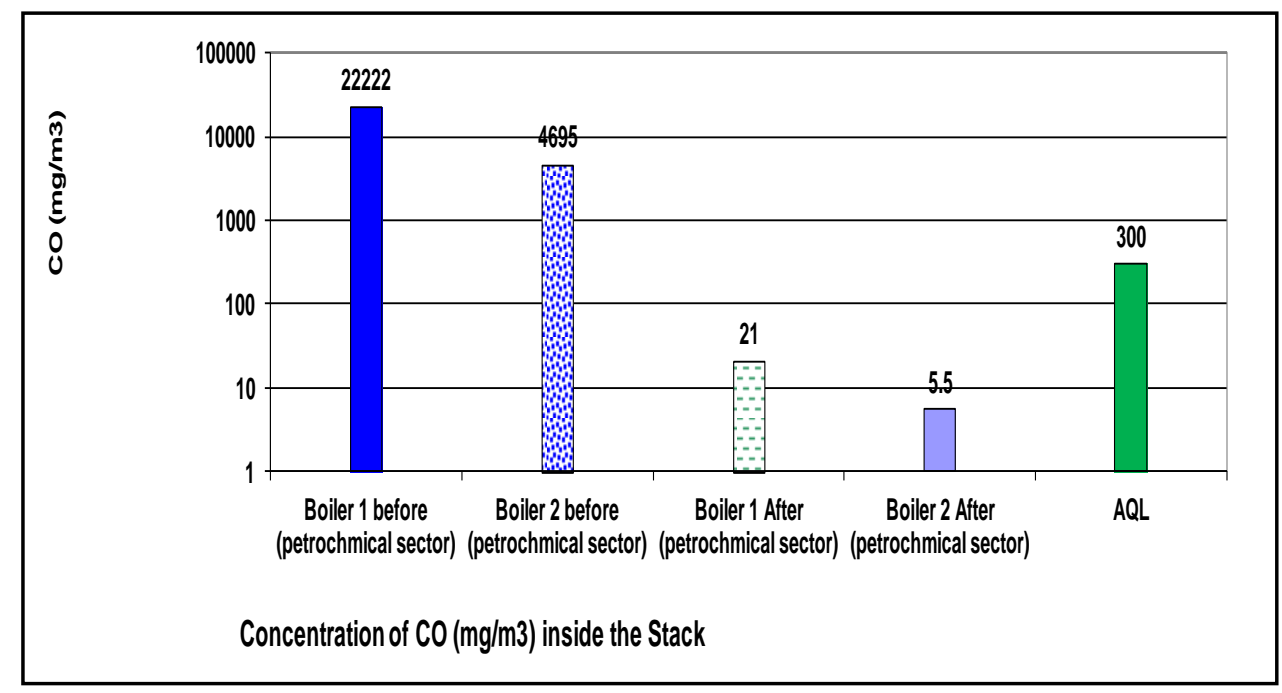

Figure 12. Concentration of $\mathrm{CO}$ from stacks of boilers in a petrochemical company 


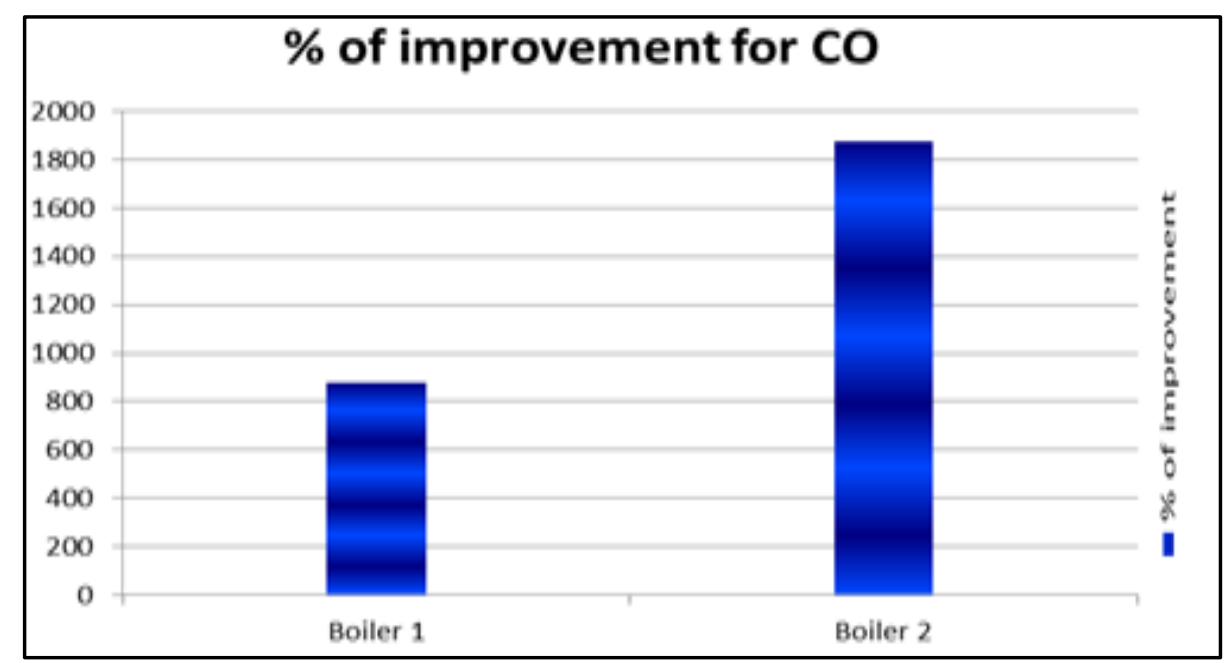

Figure 13. Percentage of $\mathrm{CO}$ improvement in two boilers in a petrochemical company

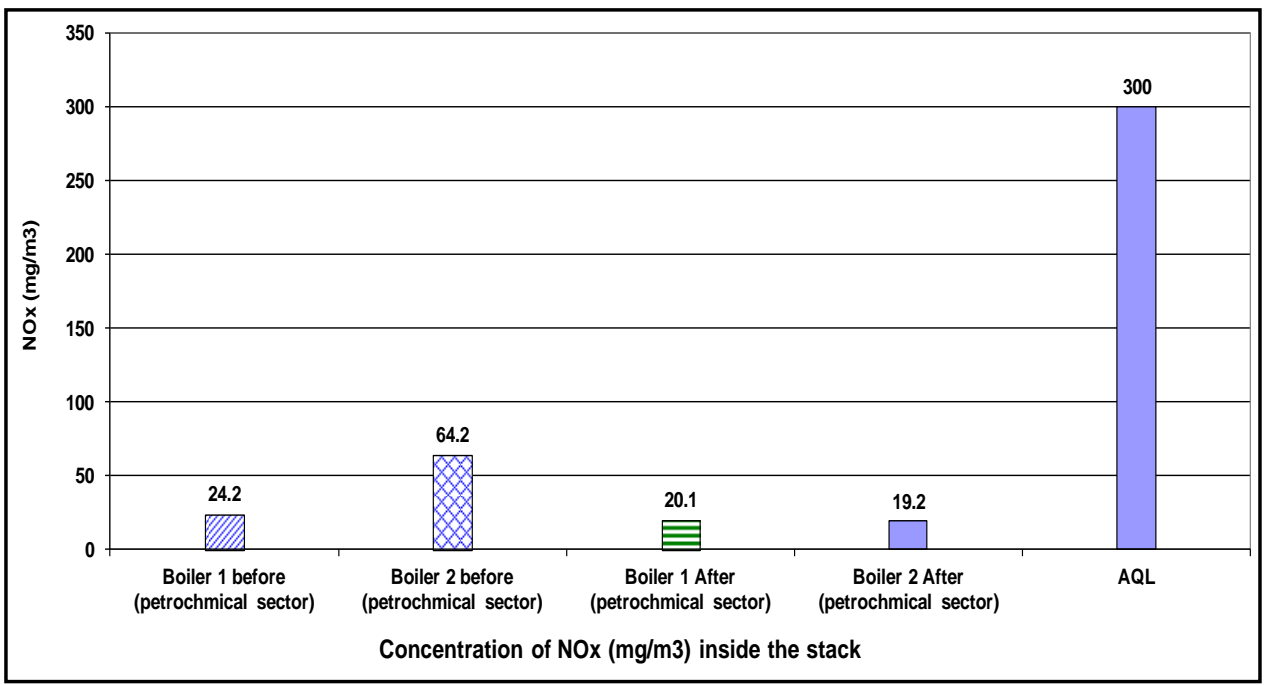

Figure 14. $\mathrm{NO}_{\mathrm{x}}$ concentration from stacks of two boilers in a petrochemical company

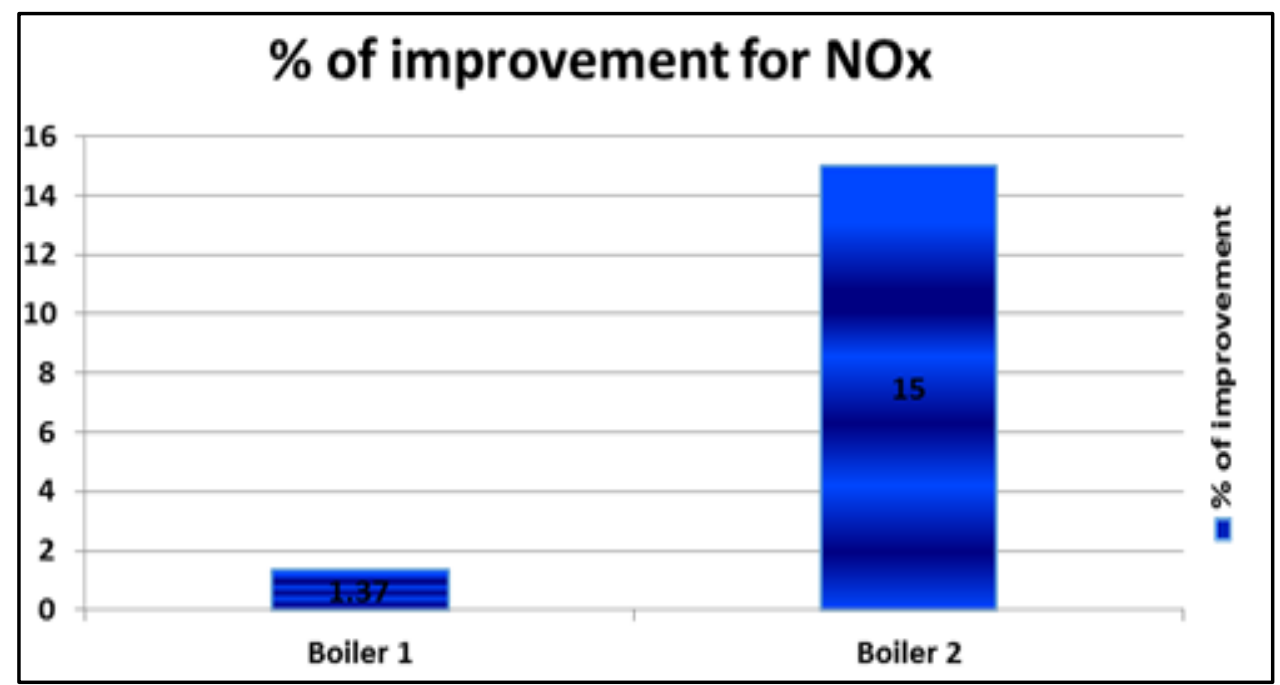

Figure 15. Percentage of $\mathrm{NO}_{\mathrm{x}}$ improvement in two boilers in a petrochemical company 


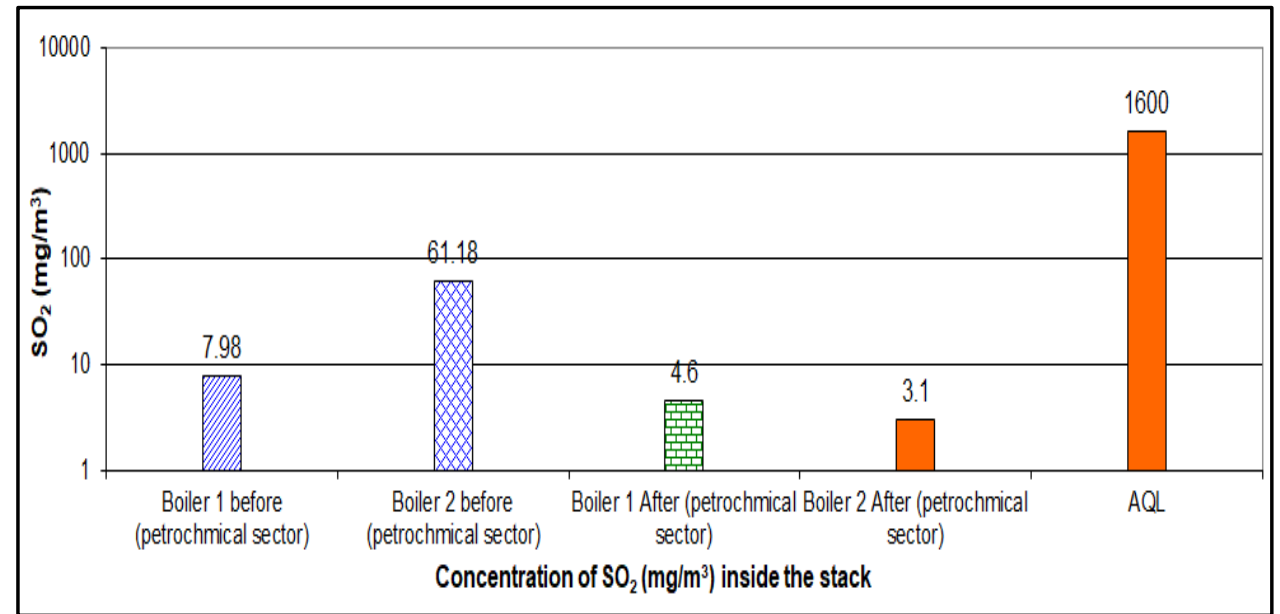

Figure 16. $\mathrm{SO}_{2}$ concentration from two boilers stacks in a petrochemical company

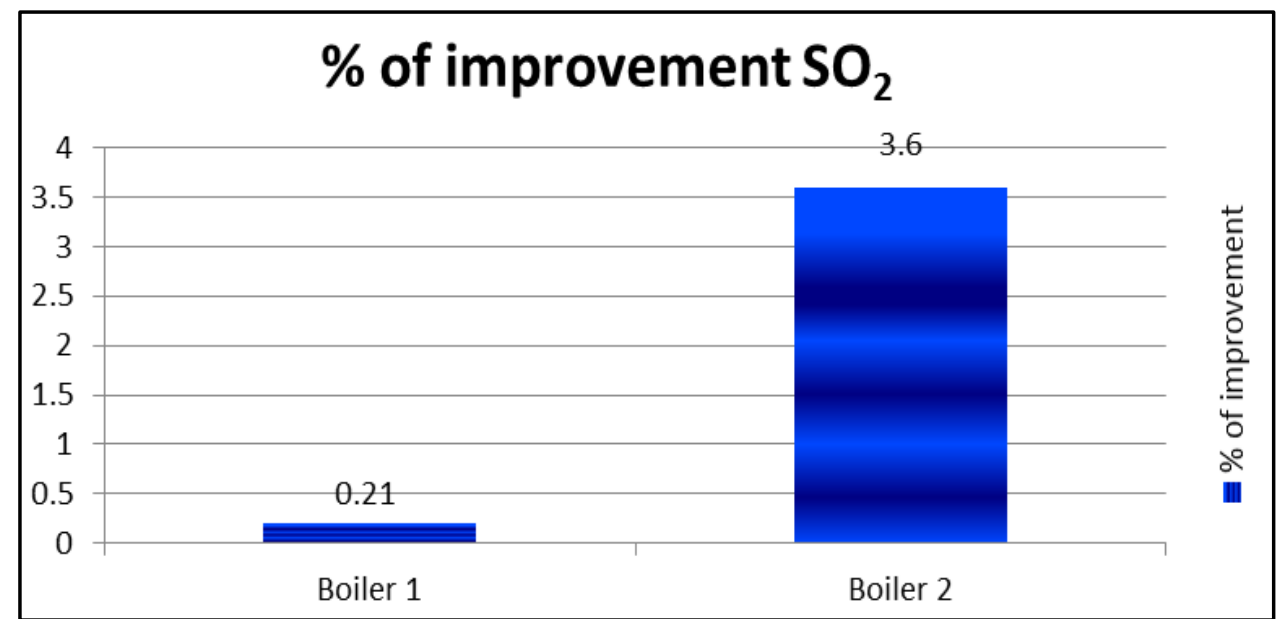

Figure 17. Percentage of $\mathrm{SO}_{2}$ improvement in two boilers in a petrochemical company

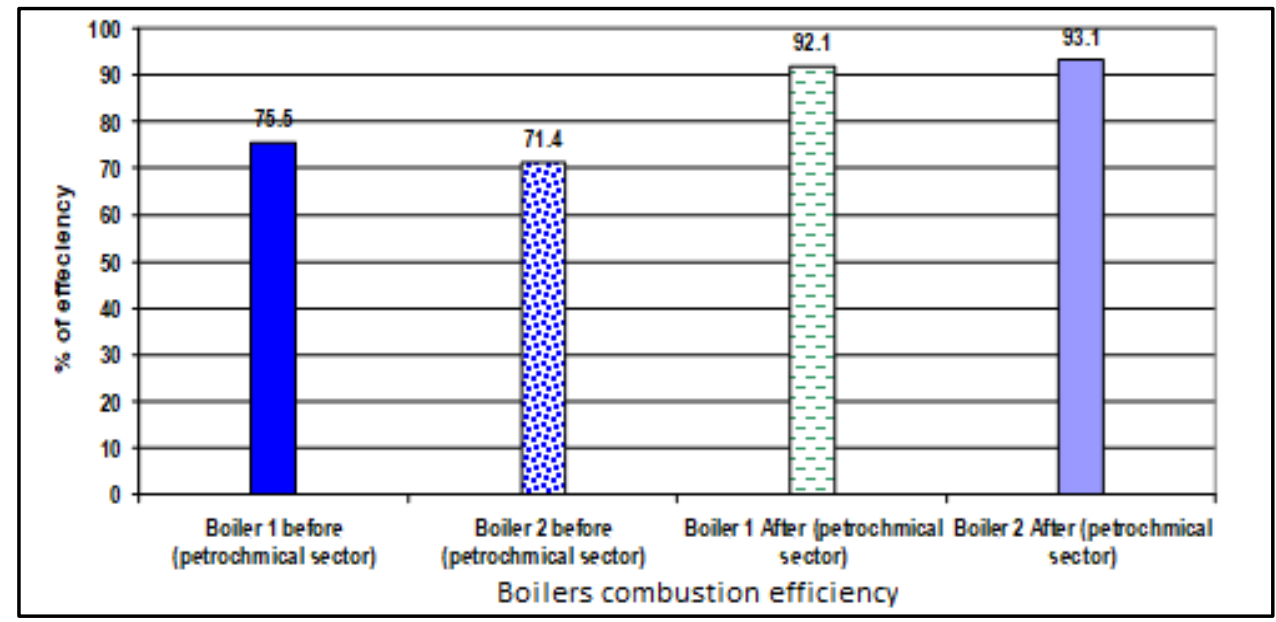

Figure 18. Efficiency improvement Percentage in two boilers in a petrochemical company 


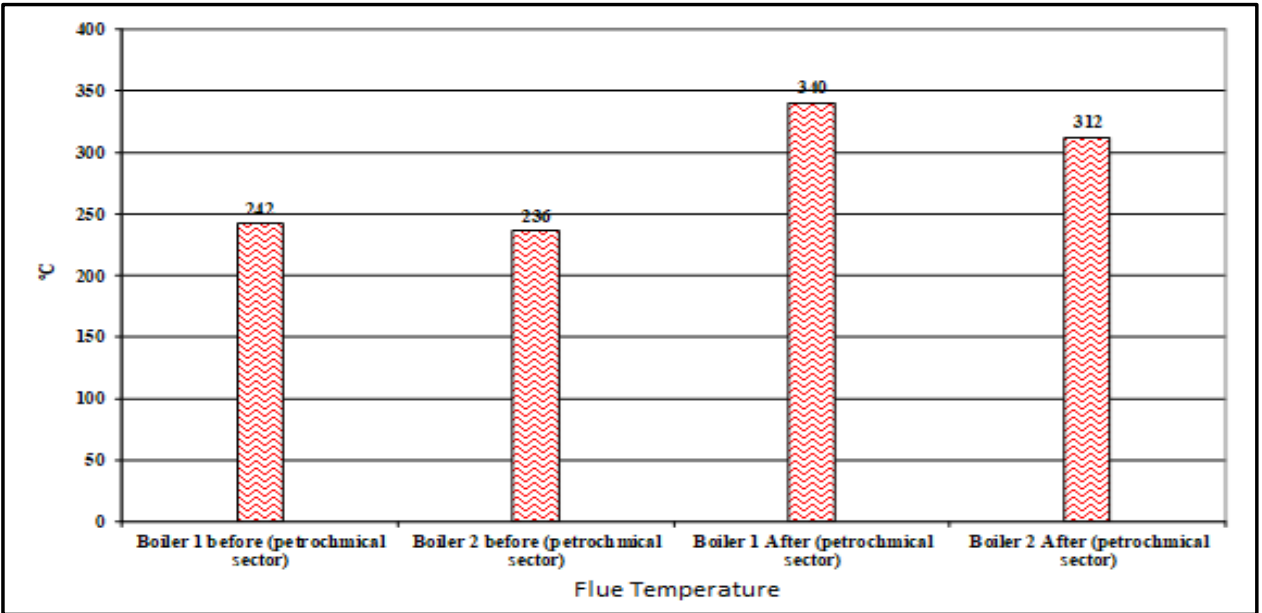

Figure 19. Flue temperature ${ }^{0} \mathrm{C}$ change in two boilers in a petrochemical company

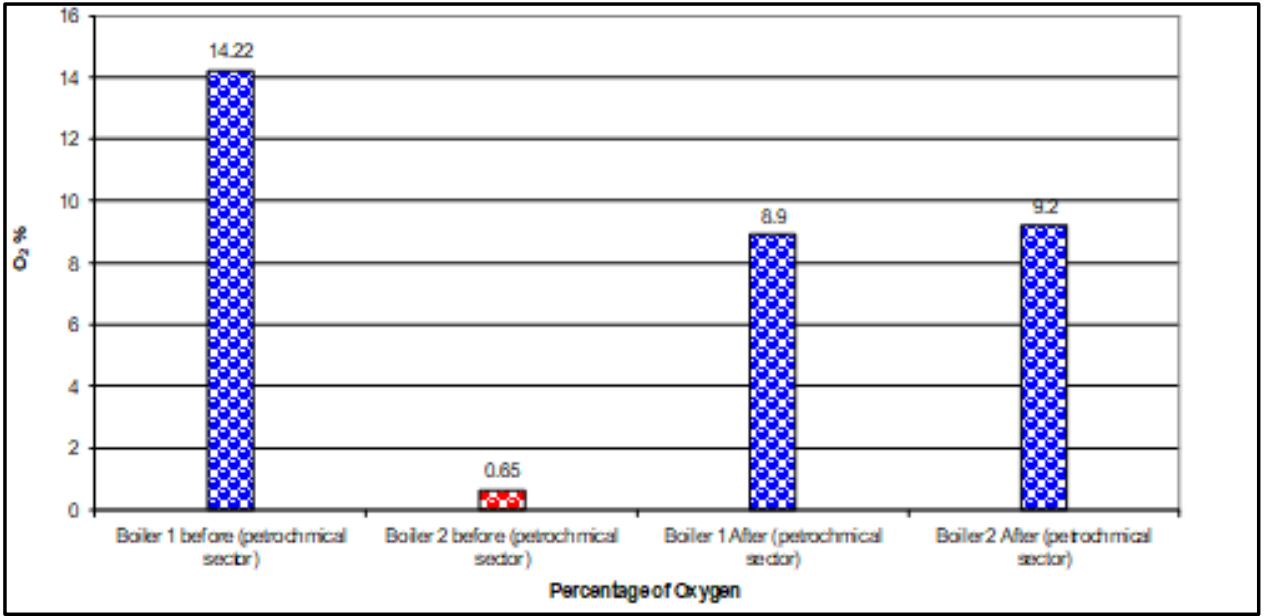

Figure 20. $\mathrm{O}_{2}$ percentage improvement of two boilers in a petrochemical company

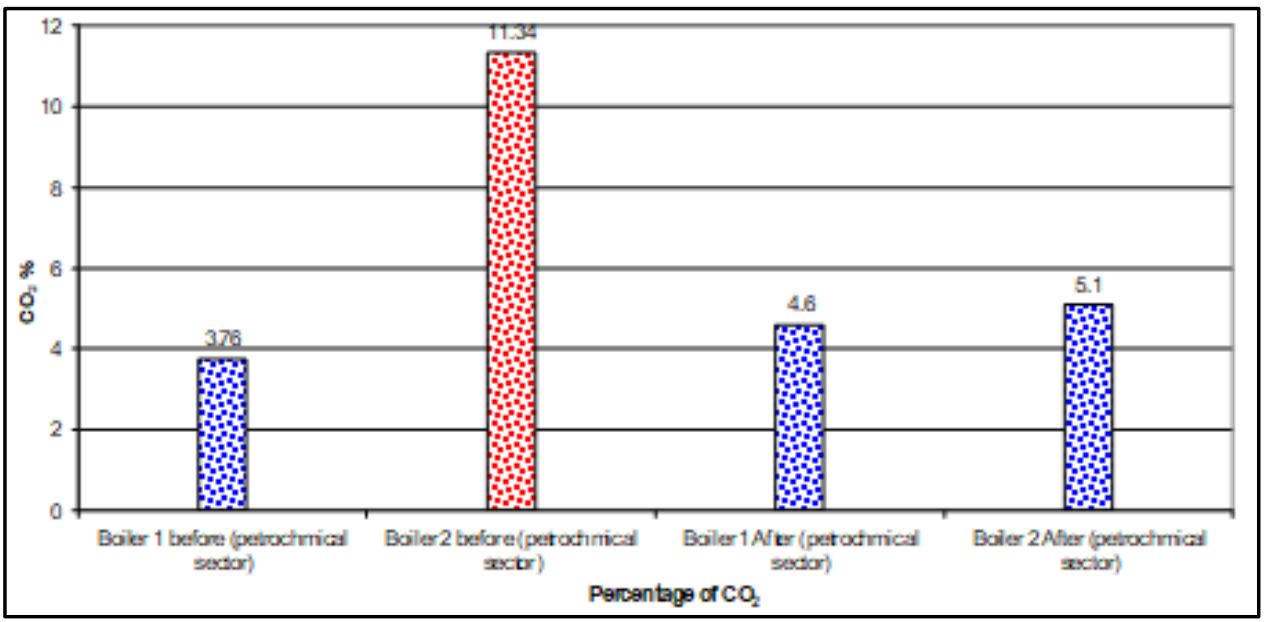

Figure 21. $\mathrm{CO}_{2}$ percentage improvement in two boilers in a petrochemical company 


\section{Macrothink}

\subsection{Measuring Data from Boilers in Food Sector}

\subsubsection{Percentage of CO Improvement in Boiler 1}

Carbone monoxide reached $2200 \mathrm{mg} / \mathrm{m}^{3}$ before any action that's mean it increased 8.8 times of AQL. So, this value reached $880 \%$ of AQL. On the other hand, the concentration of CO after corrective action (maintenance) reached $45 \mathrm{mg} / \mathrm{m}^{3}$, So the percentage of this value after maintenance reached $18 \%$. The improvement of this action was $862 \%$ as shown in figure (22 and 23) and table (2).

\subsubsection{Percentage of CO Improvement in Boiler 2}

Carbone monoxide reached $\mathbf{1 9 0 0 . 0} \mathrm{mg} / \mathrm{m}^{3}$ before any action that's mean it increased 7.6 times of AQL. So, this value reached $760.0 \%$ of AQL. On the other hand, the concentration of $\mathrm{CO}$ after the corrective action (maintenance) reached $59 \mathrm{mg} / \mathrm{m}^{3}$, So the percentage of this value after maintenance reached $23.6 \%$. The improvement of this action was $736.4 \%$ as shown in figure (22 and 23) and table (2).

Table 2. Pollutants emission from stacks of boilers in a food company

\begin{tabular}{|c|c|c|c|c|c|c|c|c|c|c|}
\hline Parameters & $\mathrm{FT}^{\circ} \mathrm{C}$ & $\mathrm{AT}^{\circ} \mathrm{C}$ & $\mathrm{O} 2 \%$ & $\mathrm{CO} 2 \%$ & $\begin{array}{l}\mathrm{CO} \\
\mathrm{mg} / \mathrm{m} 3\end{array}$ & $\begin{array}{l}\mathrm{NO} \\
\mathrm{mg} / \mathrm{m} 3\end{array}$ & $\begin{array}{l}\mathrm{NO} 2 \\
\mathrm{mg} / \mathrm{m} 3\end{array}$ & $\begin{array}{l}\mathrm{NOX} \\
\mathrm{mg} / \mathrm{m} 3\end{array}$ & $\begin{array}{l}\mathrm{SO} 2 \\
\mathrm{mg} / \mathrm{m} 3\end{array}$ & $\begin{array}{l}\text { Eff. } \\
\%\end{array}$ \\
\hline AQL & & & & & 250 & & & 300 & 1600 & \\
\hline \multicolumn{11}{|c|}{ Fuel Type: Natural Gas Food sector } \\
\hline Boiler 1 before & 234 & 30 & 12.2 & 2.76 & 2200 & 700 & 0 & 700 & 36.20 & 69.8 \\
\hline$\%$ according to $\mathrm{AQL}$ & & & & & 880 & & & 233.33 & 2.26 & \\
\hline Boiler1 after & 243 & 30 & 5.4 & 6.3 & 45 & 47 & 0 & 47 & 2.7 & 91.4 \\
\hline$\%$ according to $\mathrm{AQL}$ & & & & & 18.0 & & & 15.67 & 0.17 & \\
\hline$\%$ of improvement & & & & & 862 & & & 217.66 & 2.1 & 21.6 \\
\hline Boiler 2 before & 143 & 31 & 2.1 & 10.4 & 1900 & 550 & 0 & 550 & 24.3 & 76.5 \\
\hline$\%$ according to $\mathrm{AQL}$ & & & & & 760.0 & & & 183.33 & 1.52 & \\
\hline Boiler 2 After & 177 & 31 & 4.6 & 7.3 & 59 & 90 & 0 & 90 & 4.8 & 91.1 \\
\hline$\%$ according to $\mathrm{AQL}$ & & & & & 23.6 & & & 30.0 & 0.3 & \\
\hline$\%$ of improvement & & & & & 736.4 & & & 153.33 & 1.22 & 14.6 \\
\hline
\end{tabular}

\subsubsection{Percentage of NOx Improvement in Boiler 1}

Nitrogen oxides were higher than AQL and reached $700 \mathrm{mg} / \mathrm{m}^{3}$ before any action, that means it increased 2.33 times of AQL (233.33\% of AQL). On the other hand, the concentration of $\mathrm{NO}_{\mathrm{x}}$ after the corrective action (maintenance) reached $47.0 \mathrm{mg} / \mathrm{m}^{3}$, so the percentage of this value after maintenance reached $15.67 \%$. The improvement of this action was $217.66 \%$ as shown in figure ( $24 \& 25)$ and table (2).

\subsubsection{Percentage of NOx Improvement in Boiler 2}

Nitrogen oxides were higher than AQL and reached $550 \mathrm{mg} / \mathrm{m} 3$ before any action that's mean it increase 1.83 times of AQL (183.33\% of AQL). On the other hand, the concentration of NOx after the corrective action (maintenance) reached $90.0 \mathrm{mg} / \mathrm{m}^{3}$, so the percentage of this value after maintenance reached $30.0 \%$ the improvement of this action was $153.33 \%$ as shown in figure ( $24 \& 25)$ and table (2). 


\section{I Macrothink}

\subsubsection{Percentage of SO2 Improvement in Boiler 1}

Sulfur dioxide was within AQL in both cases before and after maintenance, but its concentration decreased from $36.2 \mathrm{mg} / \mathrm{m}^{3}$ to $2.7 \mathrm{mg} / \mathrm{m}^{3}$ after corrective action (maintenance). The improvement percentage was $2.1 \%$ as shown in figure $(26 \& 27)$ and table (2).

\subsubsection{Percentage of SO2 Improvement in Boiler 2}

Nitrogen oxides are within the limit in both cases before and after maintenance, but its concentration decreased from $24.3 \mathrm{mg} / \mathrm{m}^{3}$ to $4.8 \mathrm{mg} / \mathrm{m}^{3}$ after the corrective action (maintenance). The percentage of improvement is $1.22 \%$ as shown in figure (26 \& 27) and table (2).

\subsubsection{Percentage of Efficiency Improvement in Boiler 1 and Boiler 2 in Food Sector}

According to the improvement of all parameters such as $\mathrm{CO}, \mathrm{NO}_{\mathrm{X}}$, and $\mathrm{SO}_{2}$ the efficiency for boiler 1 and boiler 2 improved from $69.8 \%$ to $91.4 \%$, and from 76.5 to 91.1 respectively. So, all these improvements help the company to save fuel, increase the lifetime of the boiler, and decrease emissions, as shown in figure (28) and table (2).

\subsubsection{Change in Flue Temperature inside Boiler 1 and Boiler 2 in Food Sector}

The temperature of boiler 1 and boiler 2 changed from $234^{\circ} \mathrm{C}$ to $243^{\circ} \mathrm{C}$ and from $143^{\circ} \mathrm{C}$ to $177^{\circ} \mathrm{C}$ respectively as shown in figure (29) and table (2).

\subsubsection{Percentage of O2 Improvement inside Boiler 1 and Boiler 2 in Food Sector}

The percentage of $\mathrm{O}_{2}$ is one of the very important parameters, which plays an essential role incomplete combustion. Change in $\mathrm{O}_{2}$ inside boiler 1 and boiler 2 improved from $12.2 \%$ to $5.4 \%$ and from $2.1 \%$ to $4.6 \%$ respectively, according to these changes, efficiency of burning in boiler 1 and boiler 2 improved and reached suitable ration of $\mathrm{O}_{2}$. On the other hand, $\mathrm{CO}_{2}$ changed from $2.76 \%$ to $6.3 \%$ and from $10.4 \%$ to $7.3 \%$ in boiler 1 and boiler 2 respectively. All these adjustments of $\mathrm{O}_{2}$ and $\mathrm{CO}_{2}$ are indirect ways to help the company saving fuel, increasing the lifetime of the boiler, and decreasing emissions from the stacks as shown in figure (30 \& 31) and table (2).

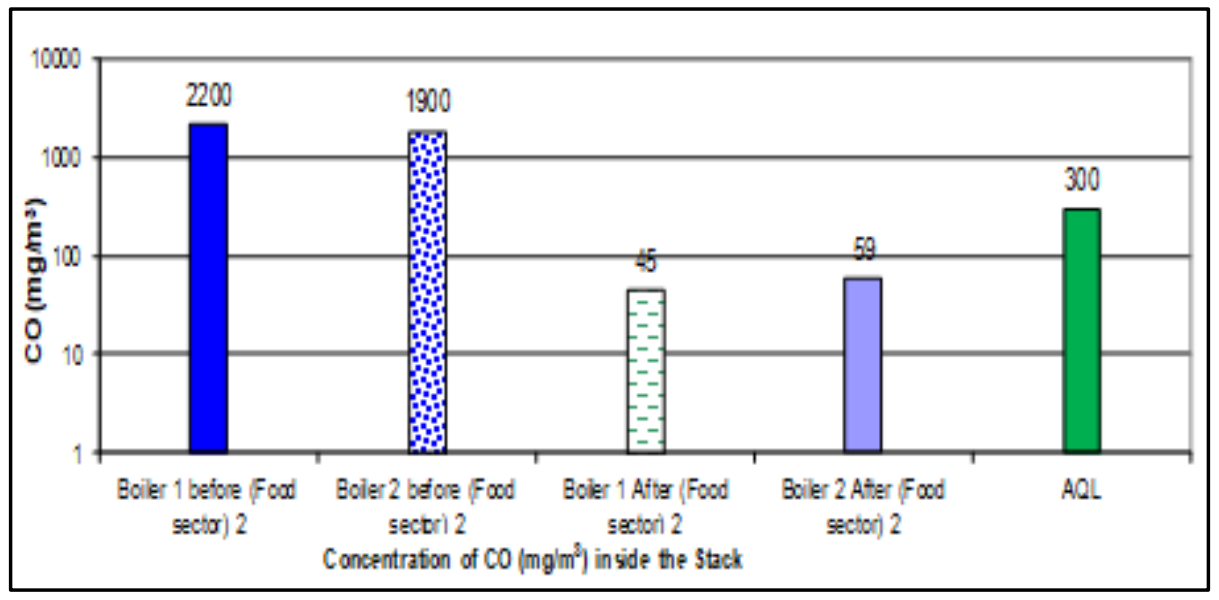

Figure 22. CO concentration from stacks of two Boilers in a food company 


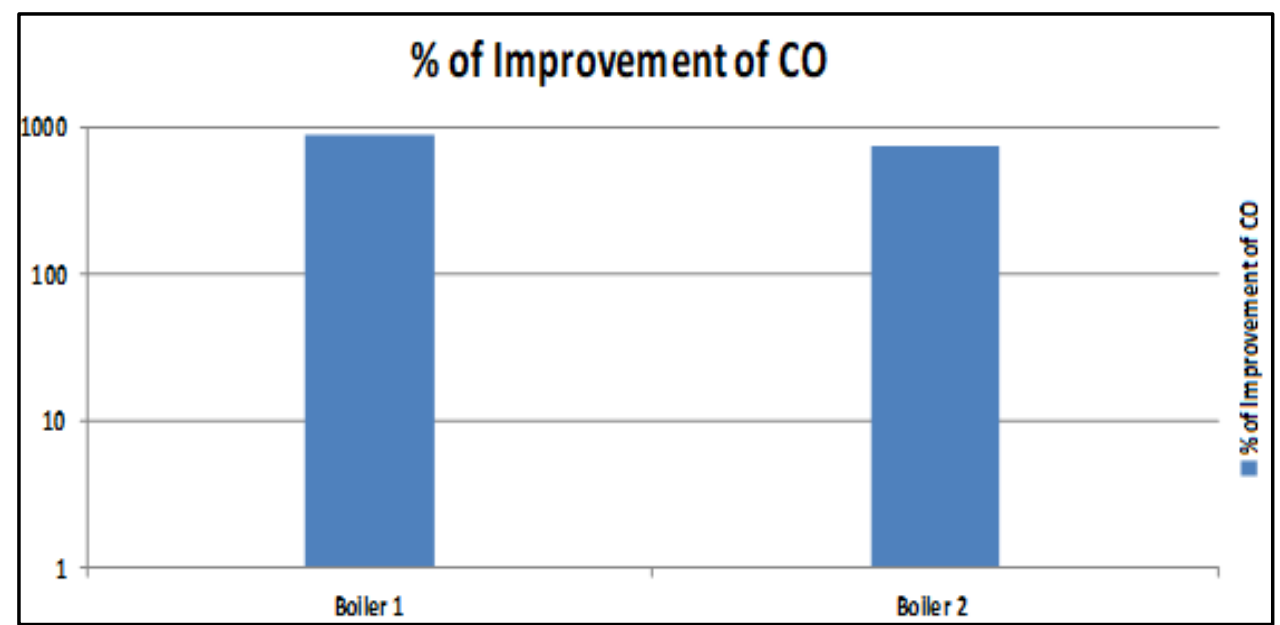

Figure 23. CO percentage of improvement in two boilers in a food company

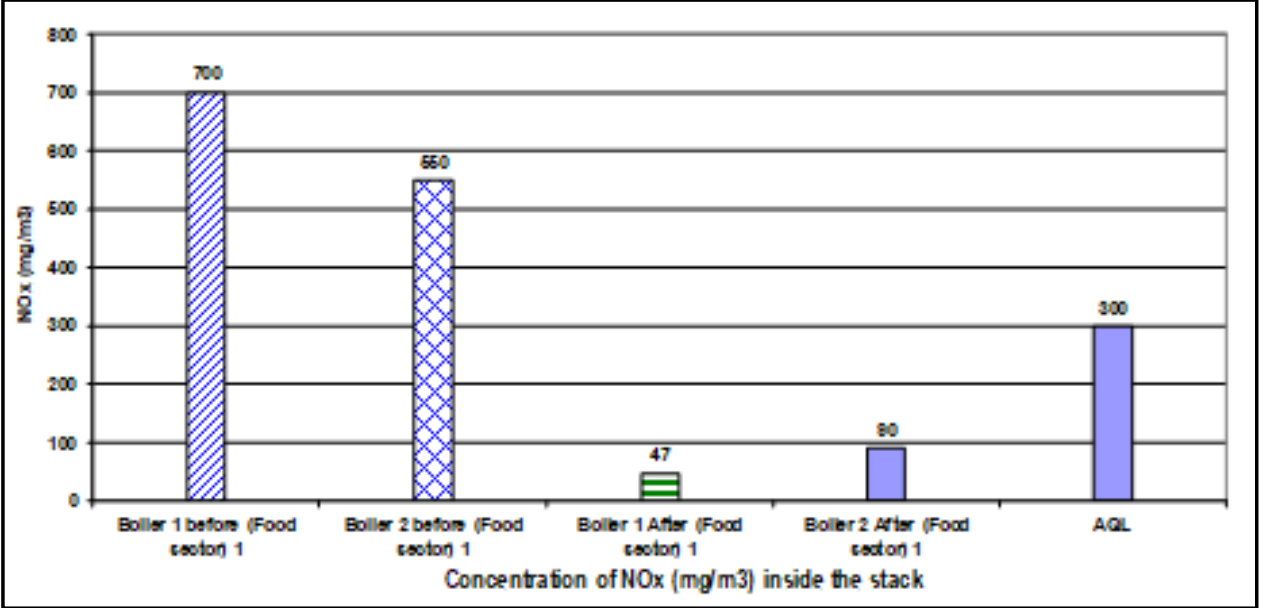

Figure 24. $\mathrm{NO}_{\mathrm{x}}$ concentration from stacks of two Boilers in a food company

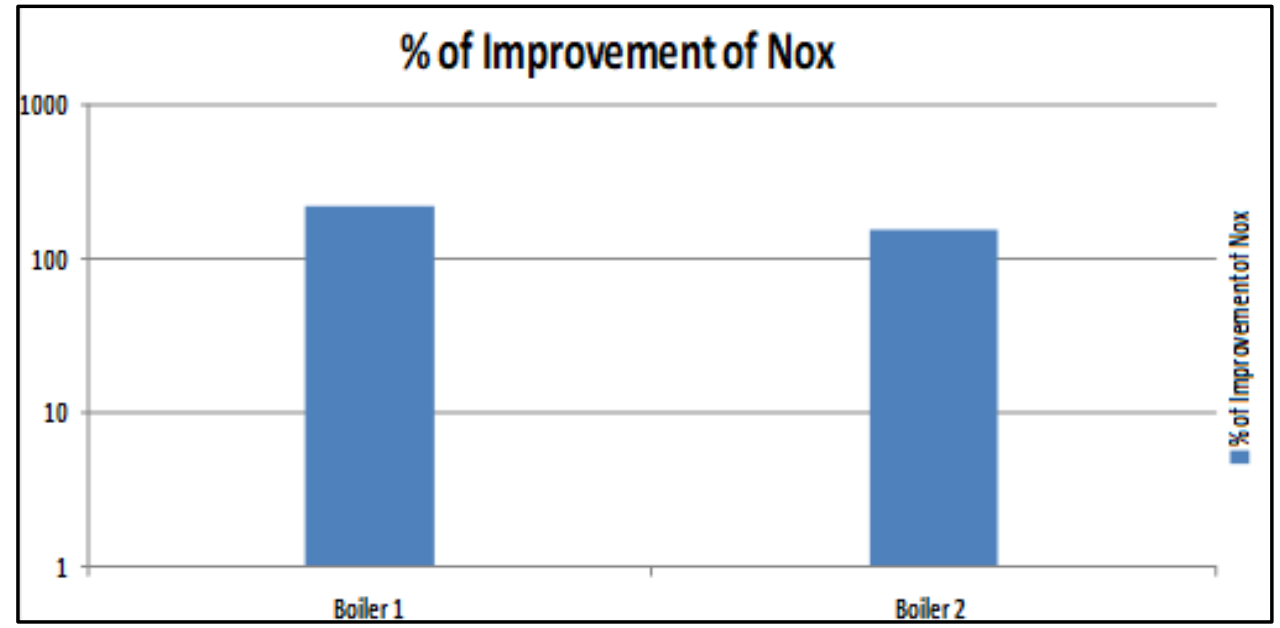

Figure $25 . \mathrm{NO}_{\mathrm{x}}$ percentage of improvement in two boilers in a food company 


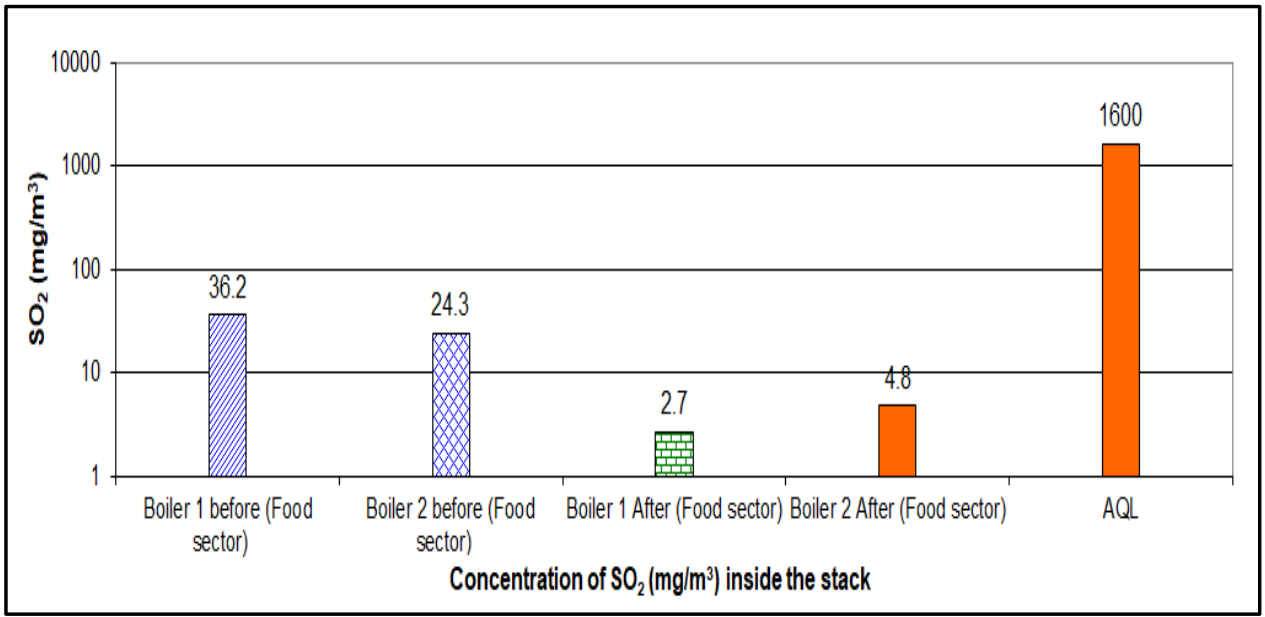

Figure 26. $\mathrm{SO}_{2}$ concentration from the stack of two Boilers in a food company

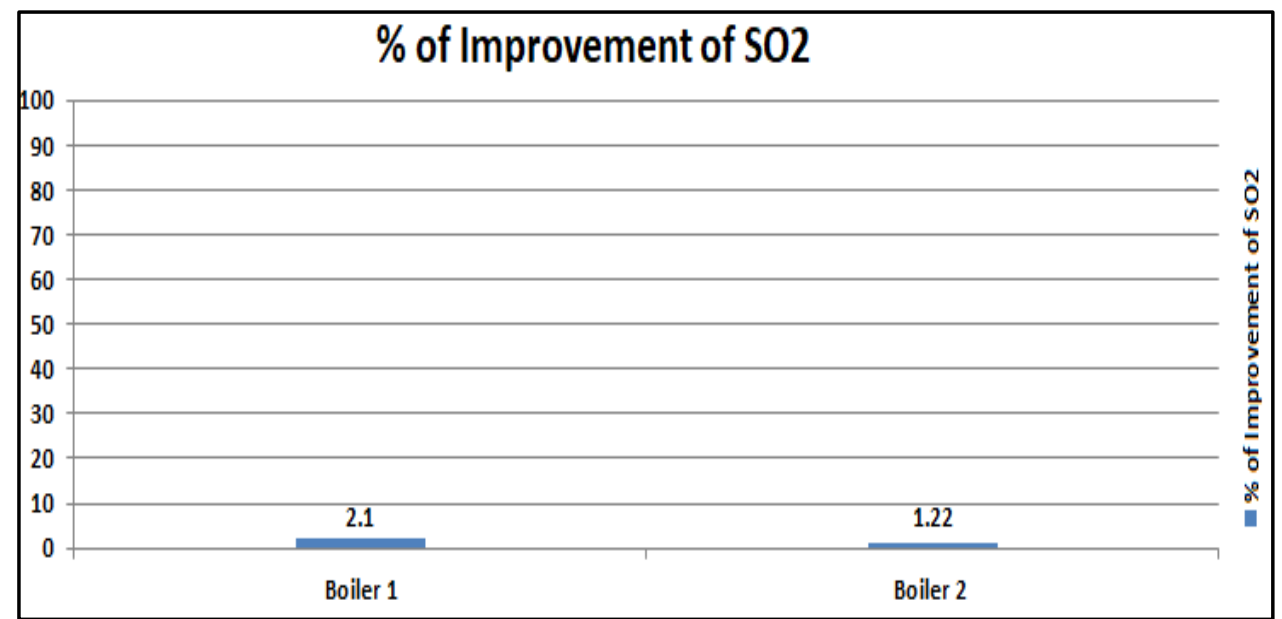

Figure 27. $\mathrm{SO}_{2}$ improvement percentage in two boilers in a food company

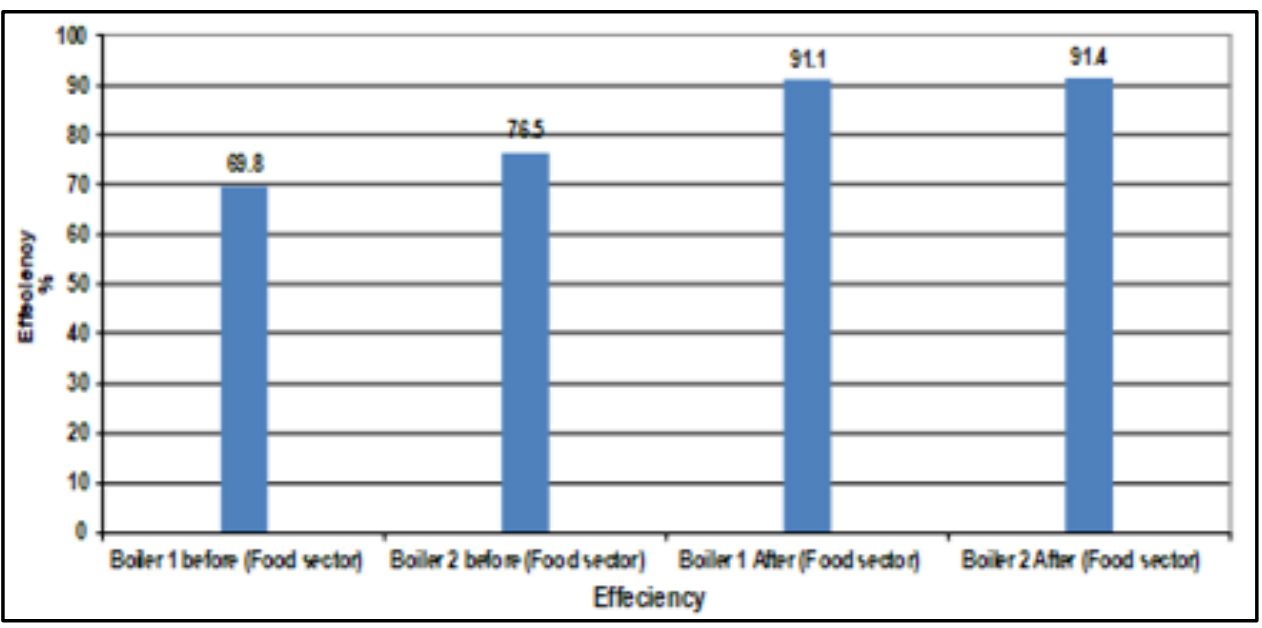

Figure 28. Efficiency improvement Percentage in two boilers in a food company 


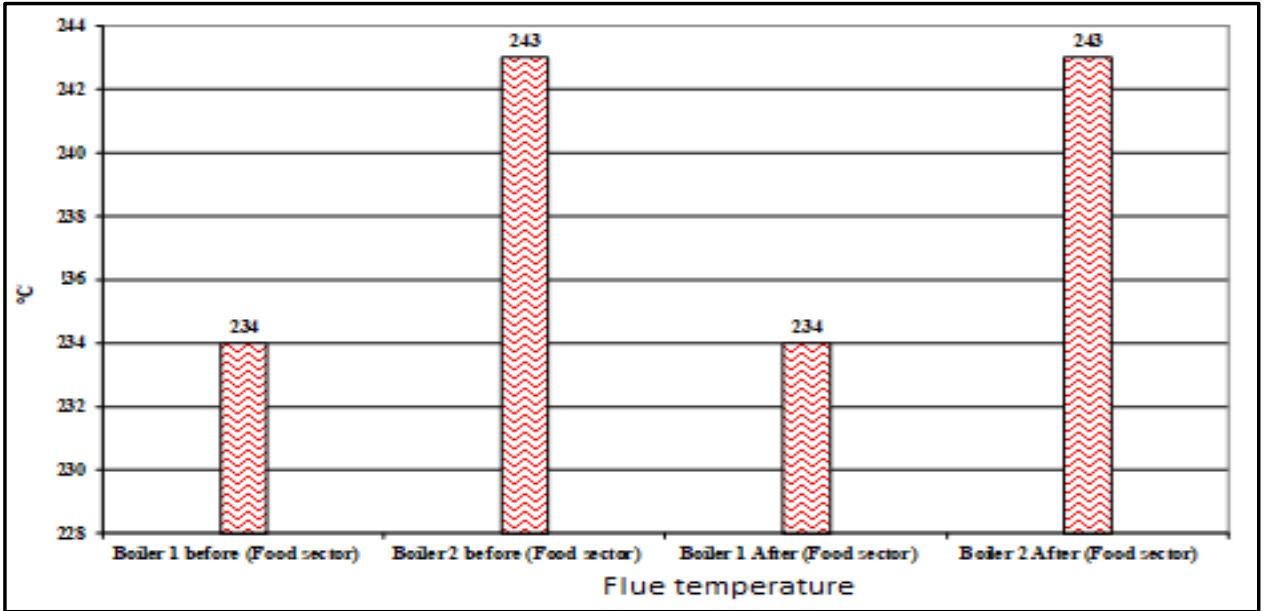

Figure 29. Flue temperature ${ }^{\circ} \mathrm{C}$ improvement in two boilers in a food company

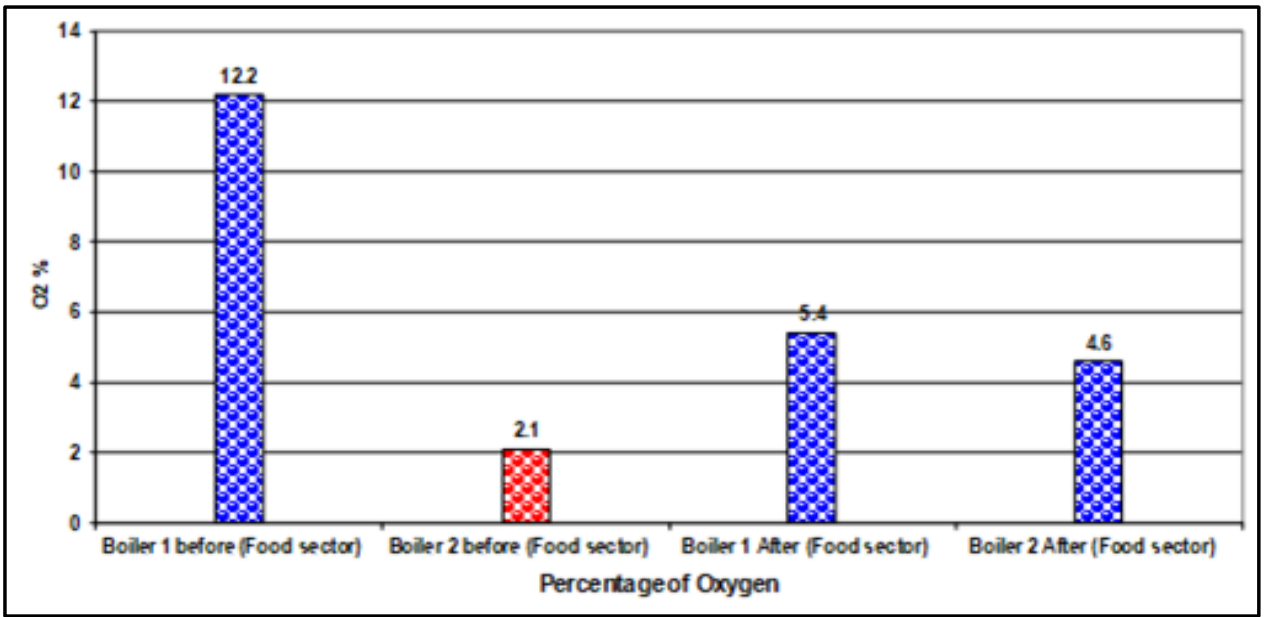

Figure $30 . \mathrm{O}_{2}$ percentage change in two boilers in a food company

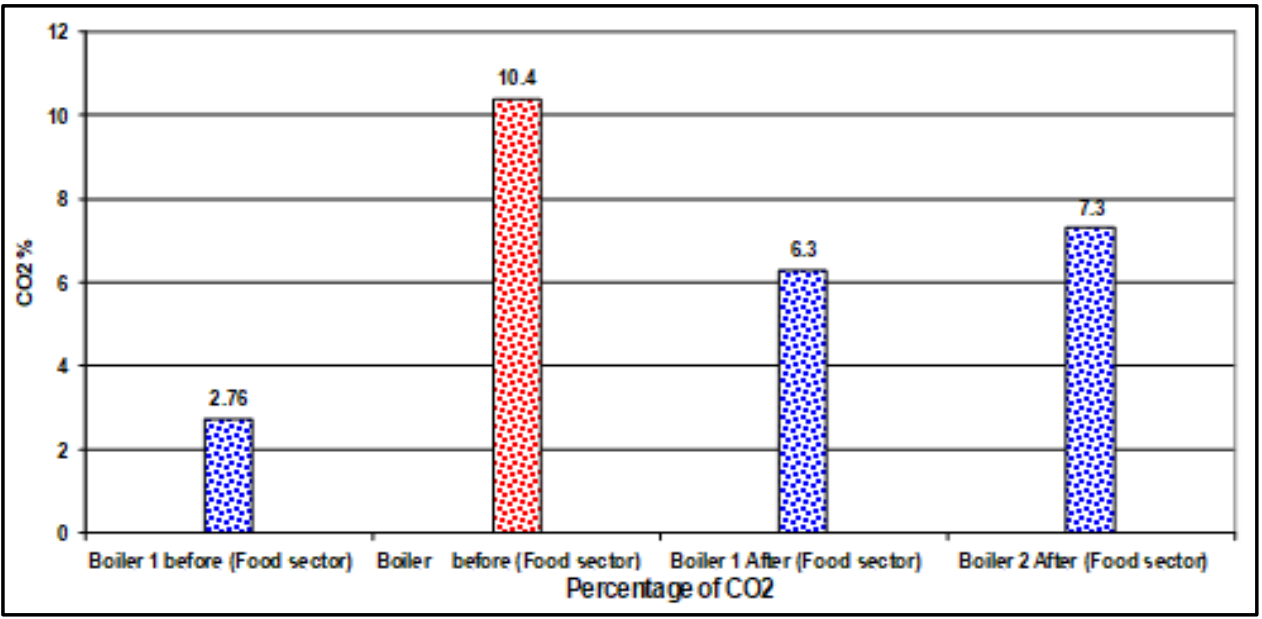

Figure 31. $\mathrm{CO}_{2}$ percentage improvement in two boilers in a food company 


\section{Macrothink}

\subsection{Stack Heat Loss}

Calculations of stack heat loss were from combustion efficiency, and fuel heat value, which can be known from the guideline of inspection on power generation units by EEAA.

In the case of annual fuel cost for each boiler is $100,000 \$$, which equals about $33,333.33$ MMBtu, where natural gas price is $3 \$$ per 1 MMBtu. We will fix the annual fuel cost $(100000 \$)$ for all boilers in petrochemical and food sectors, and hence annually produced heat before the improvement process is (33333.33 MMBtu). The annual quantity of fuel was calculated from annual heat (33333.33 MMBtu and the net calorific value of Egyptian natural gas in table 3).

Stack heat loss was calculated in both cases before and after maintenance using fuel heat value of Egyptian natural gas (net calorific value) according to the guideline of inspection on power generation units' reference, by EEAA, 2003 table (3), as shown in figure (32) and table (4).

Table 3. The Calorific value of different types of fuel in Egypt (EEAA, 2004) *

\begin{tabular}{|l|l|l|l|l|l|l|l|l|l|}
\hline \multirow{2}{*}{ Fuel } & \multicolumn{9}{l}{ Components weight (percentage) } \\
\cline { 2 - 10 } & Carbon & Hydrogen & Sulfur & Nitrogen & Oxygen & Ash & Water & Net Calorific Value & Gross Calorific value \\
\hline Natural gas & 75.0 & 25.0 & --- & --- & --- & --- & --- & 55300 & 49830 \\
\hline LPG & 82.4 & 17.6 & --- & --- & --- & --- & --- & 46860 & 43285 \\
\hline Kerosene & 86.0 & 13.7 & 0.07 & --- & --- & --- & --- & 45900 & 43030 \\
\hline Solar & 86.3 & 12.5 & 1.0 & 0.05 & 0.05 & 0.1 & --- & 44570 & 41900 \\
\hline Crude Oil & 86.0 & 10.5 & 3.0 & 0.05 & 0.05 & 0.2 & 0.2 & 43250 & 41080 \\
\hline Cane waste & 24.7 & 2.7 & 0.1 & 0.4 & 20.6 & 1.5 & 50 & 9473 & 7796 \\
\hline
\end{tabular}

*the reference is in Arabic language 


\section{Macrothink DInstitute ${ }^{T M}$}

Table 4. Calculation of stack heat loss

\begin{tabular}{|c|c|c|c|c|c|c|c|c|c|}
\hline \multicolumn{10}{|l|}{ Case studies } \\
\hline \multirow[t]{2}{*}{ parameters } & \multirow[t]{2}{*}{ Unit } & \multicolumn{4}{|c|}{ Petroleum sector } & \multicolumn{4}{|l|}{ Food Sector } \\
\hline & & $\begin{array}{l}\text { Boiler } 1 \\
\text { (before) }\end{array}$ & $\begin{array}{l}\text { Boiler } 1 \\
\text { (after) }\end{array}$ & $\begin{array}{l}\text { Boiler } 2 \\
\text { (before) }\end{array}$ & $\begin{array}{l}\text { Boiler } 2 \\
\text { (after) }\end{array}$ & $\begin{array}{l}\text { Boiler } 1 \\
\text { (before) }\end{array}$ & $\begin{array}{l}\text { Boiler } 1 \\
\text { (after) }\end{array}$ & $\begin{array}{l}\text { Boiler } 2 \\
\text { (before) }\end{array}$ & $\begin{array}{l}\text { Boiler } 2 \\
\text { (after) }\end{array}$ \\
\hline Combustion efficiency & $\%$ & 75.5 & 92.1 & 71.4 & 93.1 & 69.8 & 91.4 & 76.5 & 91.1 \\
\hline$\%$ of com. Eff. improvement & $\%$ & \multicolumn{2}{|l|}{16.6} & \multicolumn{2}{|l|}{21.7} & \multicolumn{2}{|l|}{21.6} & \multicolumn{2}{|l|}{14.6} \\
\hline fuel Saving & $\%$ & \multicolumn{2}{|l|}{18.0} & \multicolumn{2}{|l|}{23.3} & \multicolumn{2}{|l|}{23.6} & \multicolumn{2}{|l|}{16.0} \\
\hline Annual quantity of fuel consumed & $\mathrm{Kg}$ & 635958.9 & 521359.2 & 635958.9 & 487716.9 & 635958.9 & 485681.8 & 635958.9 & 543108.9 \\
\hline Net Calorific Value (natural gas) & $\mathrm{kj} / \mathrm{kg}$ & 55300.0 & 55300.0 & 55300.0 & 55300.0 & 55300.0 & 55300.0 & 55300.0 & 55300.0 \\
\hline Stack heat loss $/ \mathrm{Kg}$ & $\mathrm{Kj}$ & 13548.5 & 4368.7 & 15815.8 & 3815.7 & 16700.6 & 4755.8 & 12995.5 & 4921.7 \\
\hline Stack heat loss/year & $\mathrm{Kj}$ & 8616289712.1 & 2277661937.0 & 10058198770.6 & 1860981375.3 & 10620895205.3 & 2309805552.0 & 7057971710.0 & 2673019073.1 \\
\hline Stack heat loss/year & MMBtu & 8166.7 & 2158.8 & 9533.3 & 1763.9 & 10066.7 & 2189.3 & 6689.7 & 2533.5 \\
\hline Saved heat & MMBtu & \multicolumn{2}{|l|}{6007.9} & \multicolumn{2}{|l|}{7769.4} & \multicolumn{2}{|l|}{7877.4} & \multicolumn{2}{|l|}{4156.2} \\
\hline $\begin{array}{l}\text { Cost reduction from } \\
\text { heat saving /year }\end{array}$ & $\$ /$ year & \multicolumn{2}{|l|}{18023.7} & \multicolumn{2}{|l|}{23308.2} & \multicolumn{2}{|l|}{23632.2} & \multicolumn{2}{|l|}{12468.6} \\
\hline
\end{tabular}

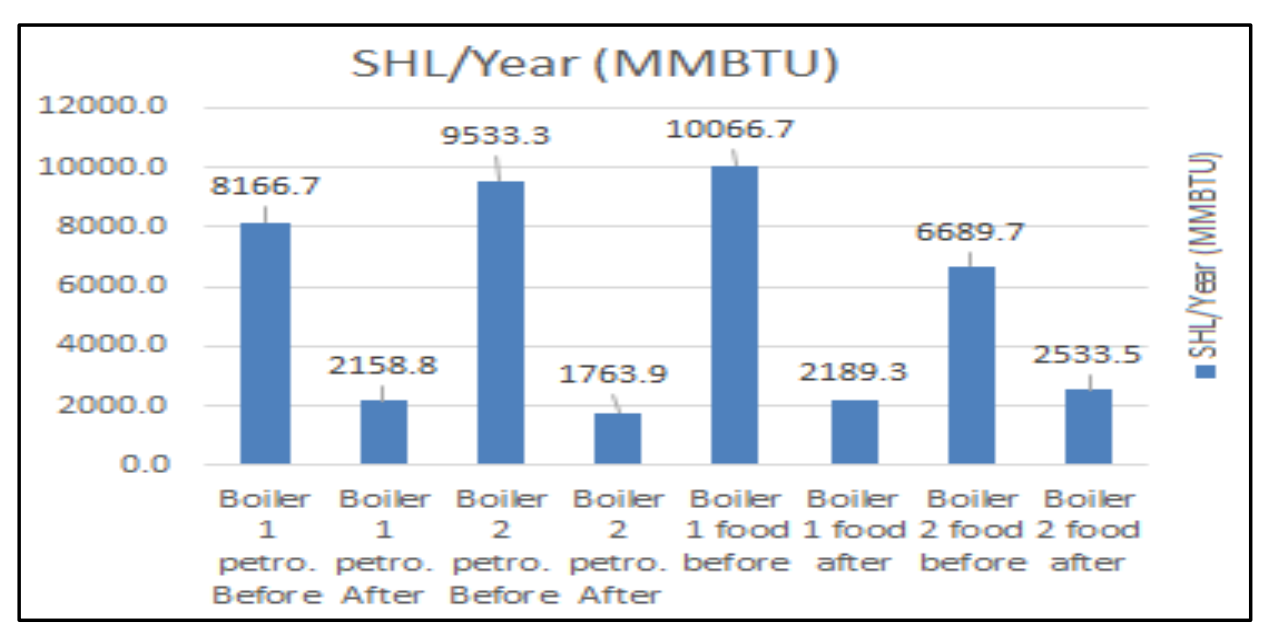

Figure 32. Stack heat loss decreasing after improvement in all boilers 


\subsection{Fuel Saving}

Calculation of estimated fuel saving from measured combustion efficiency improvement in boilers according to equation 4 . Table 4 and figure 33 shows the fuel-saving in four boilers at petrochemical and food sectors.

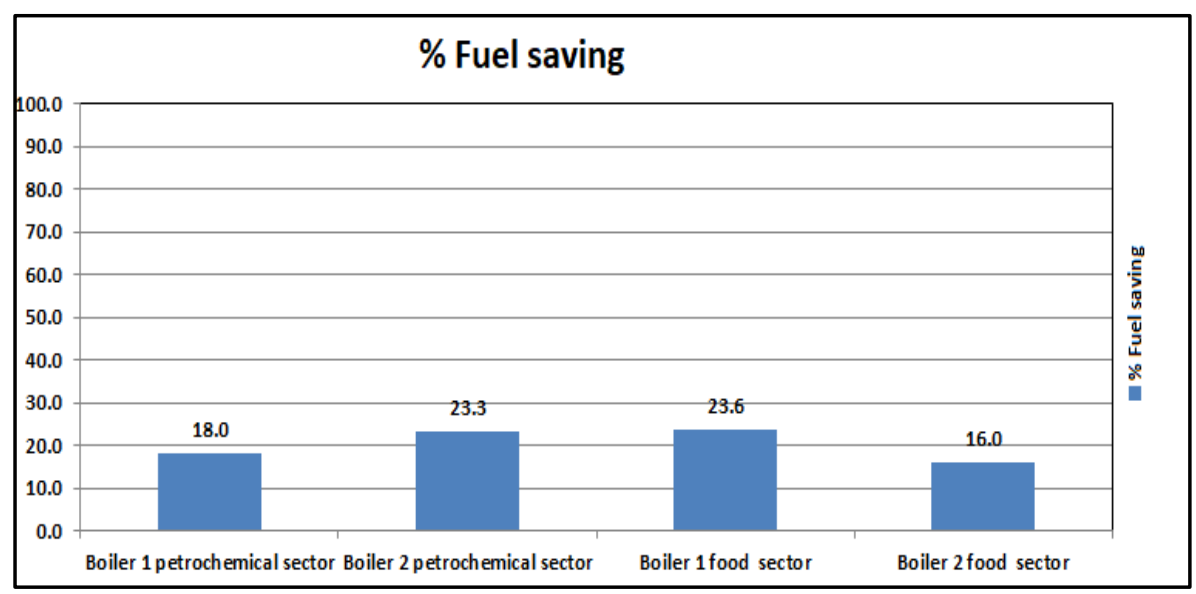

Figure 33. Percentage of fuel saving in the four boilers at petrochemical and food sectors

\subsection{Cost Reduction and Payback Time}

In case of annual fuel cost for each boiler is $100000 \$$, and the corrective action (maintenance) cost for each boiler is 15000 , so the payback time according to equation 7 and considering that the cost of installation is the cost of maintenance, the results shown in figure (34) and table (6).

Table 6. the annual saving cost (\$) and payback time (year)

\begin{tabular}{|l|l|l|l|l|l|l|}
\hline Sector & Boiler & $\begin{array}{l}\text { \% of Fuel } \\
\text { saving }\end{array}$ & $\begin{array}{l}\text { Saving Cost } \\
\text { \$/year }\end{array}$ & $\begin{array}{l}\text { Payback time } \\
\text { (Year) }\end{array}$ & $\begin{array}{l}\text { Payback time } \\
\text { (Month) }\end{array}$ & $\begin{array}{l}\text { Payback time } \\
\text { (Day) }\end{array}$ \\
\hline \multirow{2}{*}{ Petrochemical } & Boiler 1 & 18.0 & 18023.7 & 0.83 & 9.99 & 300 \\
\cline { 2 - 6 } & Boiler 2 & 23.3 & 23308.2 & 0.64 & 7.72 & 232 \\
\hline \multirow{2}{*}{ Food } & Boiler 1 & 23.6 & 23632.2 & 0.64 & 7.62 & 229 \\
\cline { 2 - 6 } & Boiler 2 & 16.0 & 12468.4 & 1.20 & 14.00 & 433 \\
\hline
\end{tabular}

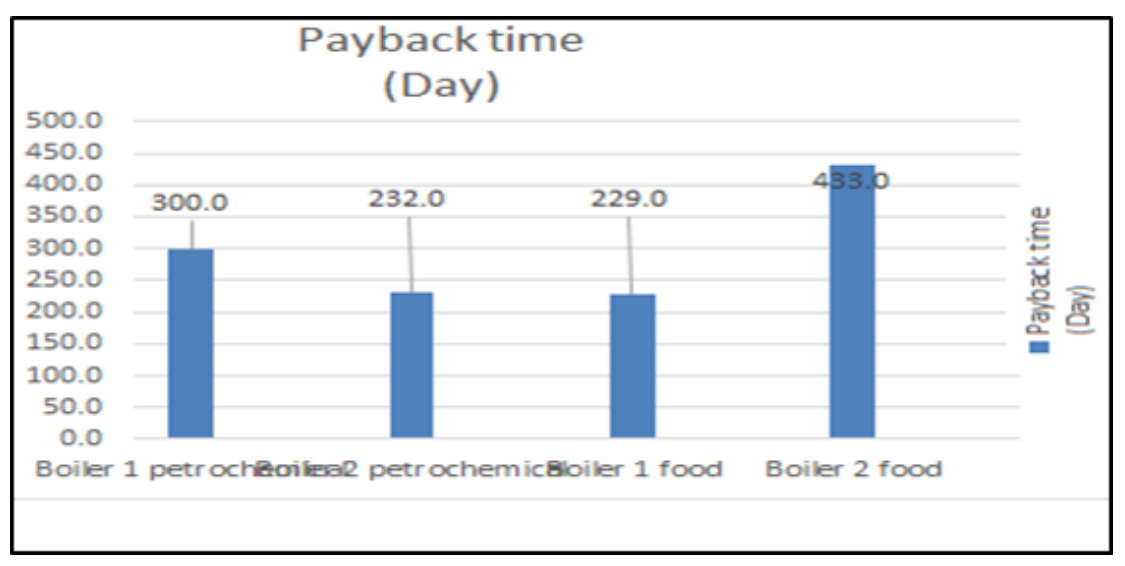

Figure 34. Payback time (day) for maintenance cost 


\section{Macrothink}

Environmental Management and Sustainable Development

ISSN 2164-7682

2020, Vol. 9, No. 1

\section{Conclusions}

Periodic maintenance of boilers, adjusting excess air ratio, and good mixing with fuel in combustion process is one of pollution control methods which cause increasing of combustion efficiency, boiler lifetime increase, decreasing of stack pollutants emission concentration to be compatible with national and international standards, and decreasing the fuel cost and combustion process.

Although the maintenance process may cost money at the first time, it decreases stack heat loss and fuel consumption, where the payback time may be lower than one year.

\section{Acknowledgement}

This work was supported by AMATEC Consulting Foundation for Environmental \& Scientific Assistance.

\section{References}

BBC. (2019). Making use of energy, Cost effectiveness and payback time. [Online] Available: https://www.bbc.co.uk/bitesize/guides/z3xb4qt/revision/7

Cooper, C. D., \& Alley, F. C. (1986). Air pollution control: A design Approach (1 ${ }^{\text {st }}$ ed.). Boston: PWS Publishers.

Dincer, C. Z. (2011). Sustainable Energy Systems and Application (1 ${ }^{\text {st }}$ ed.). Switzerland: Springer.

Doyle, B. W. (2003). Combustion Source Evaluation (Student Manual). Air Pollution Training Institute (APTI), United States Environmental Protection Agency (US EPA). [Online] Available: http://www.4cleanair.org/APTI/427combined.pdf

EEAA. (2003). The inspection Guideline on power generation.

Gearo J. R., \& Lappan, J. (1983). Combustion efficiency optimization manual for operator of oil and gas fired boiler. US Environmental Protection Agency (US EPA).

Global Burden of Disease Collaborative Network. (2018). Global Burden of Disease Study 2017 (GBD 2017) Results. Seattle, United States: Institute for Health Metrics and Evaluation (IHME). [Online] Available: https://ourworldindata.org/outdoor-air-pollution

Knospe, B., \& Walleser, L. (2004). Flue Gas Analysis in Industry (Practical guide for Emission and Process Measurements). USA: Testo. [Online] Available: http://www.testo350.com/downloads/Flue_Gas_in_Industry_0981_2773.pdf

Kuprianov I. V. (2005). Application of Cost-Based Method of Excess Air Optimization for the Improvement of Thermal Efficiency and Environmental Performance of Steam Boilers. Renewable and Sustainable Energy Reviews, 5(9), 474-498.

https://doi.org/10.1016/j.rser.2004.05.006

Madur Electronics. Stack Gas Analyzer Sensonic 2000 (Operating Manual). Austria. 


\section{Macrothink}

Muhammad, U. L., Shamsuddin, I. M., Danjuma A., Musawa, R. S., \& Dembo, U. H. (2018). Petroleum Science and Engineering, 1(2), 44-4. https://doi.org/10.11648/j.pse.20180201.17

Sengupta, S., \& Venkatachalam, P. (1994). Health Hazard Assessment in Industrial Town with the help of GRAM-GIS. Environmental Monitoring and Assessment, 32, 155-160. https://doi.org/10.1007/BF00547133

TSI incorporated. (2004). Combustion Analysis Basics An Overview of Measurements, Methods and Calculations used in Combustion Analysis. [Online] Available: https://www.tsi.com/getmedia/02417ee5-cccc-4dc7-80bc-f7f10924d20a/CA-basic-2980175?e $\mathrm{xt}=. \mathrm{pdf}$

United Nations Environment Programme (UNEP). (2006). Energy Efficiency Guide for Industry in Asia. [Online] Available: www.energyefficiencyasia.org

\section{Copyright Disclaimer}

Copyright for this article is retained by the author(s), with first publication rights granted to the journal.

This is an open-access article distributed under the terms and conditions of the Creative Commons Attribution license (http://creativecommons.org/licenses/by/3.0/). 